\title{
$300 \mathrm{~mm}$ 管における気液二相流実験 ${ }^{*}$
}

\section{Two-Phase Flow Study Using 300mm Diameter Pipe}

\author{
亀 田 泰 武 $^{* *}$ \\ KAMEDA Yasutake
}

\author{
森田泰治郎 \\ MORITA Taijiro
}

\begin{abstract}
A bstract Two Phase flow experiment was conducted using a $300 \mathrm{~mm}$ diameter, $100 \mathrm{~m}$ long straight pipe with adjustable gradient. A cast-iron with, in part, transparent plastic pipe was used. Superficial water and air velocities were somewhat low, ranging from 0 to $3 \mathrm{~m} / \mathrm{s}$ and 0 to $20 \mathrm{~m} / \mathrm{s}$. The data show scattering by intermittent flow to be unstable. Test results are as follows,

1. Observed flow pattern in the horizontal pipe shows that the boundary between intermittent flow and separate flow is almost the same as that of lately published results. But flow pattern is much more sensitive to pipe gradient, with a degree of $1 / 1000$. Down gradient flow shows a wide separated pattern and the up gradient flow shows intermittent flow throughout almost all the area.

2. The void ratio is also sensitive to pipe gradient. In horizontal and up gradient flow, void ratio seems to show similar value to when the ratio of superficial air velocity to superficial water velocity is equivalent.

3. Empirical formula of the pressure loss at various superficial water and air velocities was obtained.

4. Empirical formula of the effect of the pipe gradient on the pressure loss was achieved. Tests will be carried out successively to gain further information.
\end{abstract}

Keyword: Experimental study, Large diameter, Pipe gradient, Flow pattern, Pressure loss, Void ratio, Empirical formula

\section{1.はじめに}

大口径管の気液二相流の状況の解明については、実験装置が大がかりになることもあって、 これまであまり実施されていない状況である。

しかし、Simpson等の実験によって、圧力損失などこれまでの解析結果と違ら状況にあるら しいことがわかっている。一方、開水路の流れから考光て大口径管で二相流に影響を与える新 たな因子として管勾配が考えられる。

\footnotetext{
* 1989. 11. 13 受付

** 日本下水道事業団大阪支社 $\bar{T} 541$ 大阪市中央区淡路町3丁目3番地7号 TEL(06)-203-7661

*** 財団法人 建設技術研究所 T356 埼玉県川越市萓沼2503 TEL(0492)-35-3495
} 

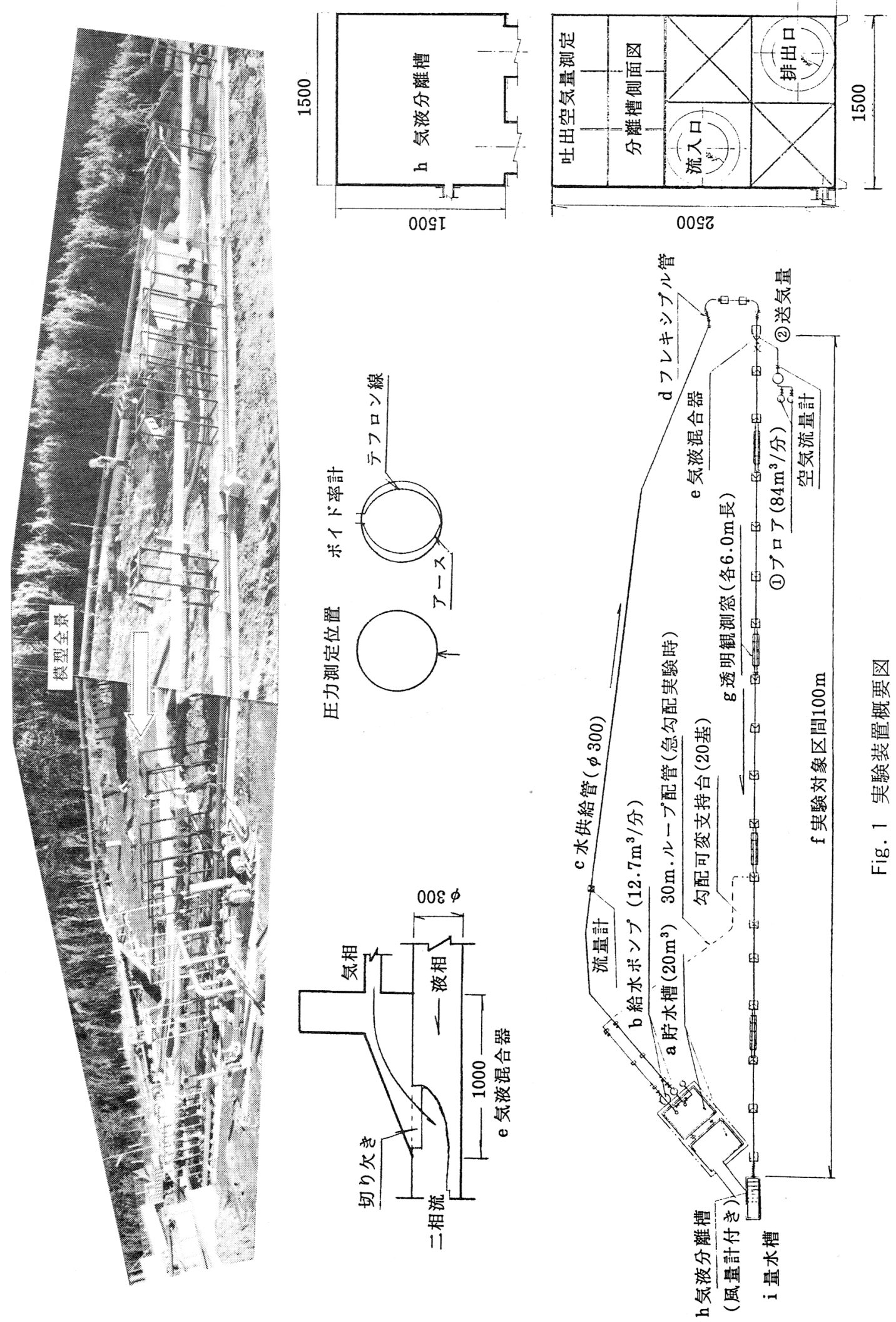
今回、内径 $300 \mathrm{~mm}$ 、直線延長 $100 \mathrm{~m}$ の勾配の多少変動できる実験装置を製作し、気・液各相 の流速、管勾配を変化させた場合の流動様式、ボイド率、圧力損失のデータを計測してそれの 解析を行らこととした。

なお、本文で使用する主な記号は次のとおりである。
$A \quad$ : 断面積
$D$ ：管径
g : 重力加速度
$I \quad$ : 管路勾配
$I_{M} \quad$ : 圧力損失勾配
$r$ : 半径
$V \quad$ : 流速（ $V_{S_{A}}$ : 空気みかけ流速、
$I_{L O} \quad$ : 満管時の $I_{M}$
$L \quad$ : 管全長、長さ
$n \quad$ : Manning の粗度係数
$R$ : 径深（流体面積／流体辺長）

\section{$V_{S L}$ : 水みかけ流速）}
$X \quad$ : Lockhart-Martinelli パラメータ
$\alpha \quad:$ ボイド率
$\gamma \quad$ : 比重量
$\lambda \quad$ : 管摩擦係数
$\rho \quad$ : 密度

\section{2. 実験装置の概要}

2. 1 構成

基本的には、循環式管路流実験装置に空気注入口と気液分離槽を加えたもので、その概要を Fig. 1 に、実験装置を構成している要素の名称と機能の概要をTable 1 に示す。

Table 1 実験装置の構成要素の名称と機能

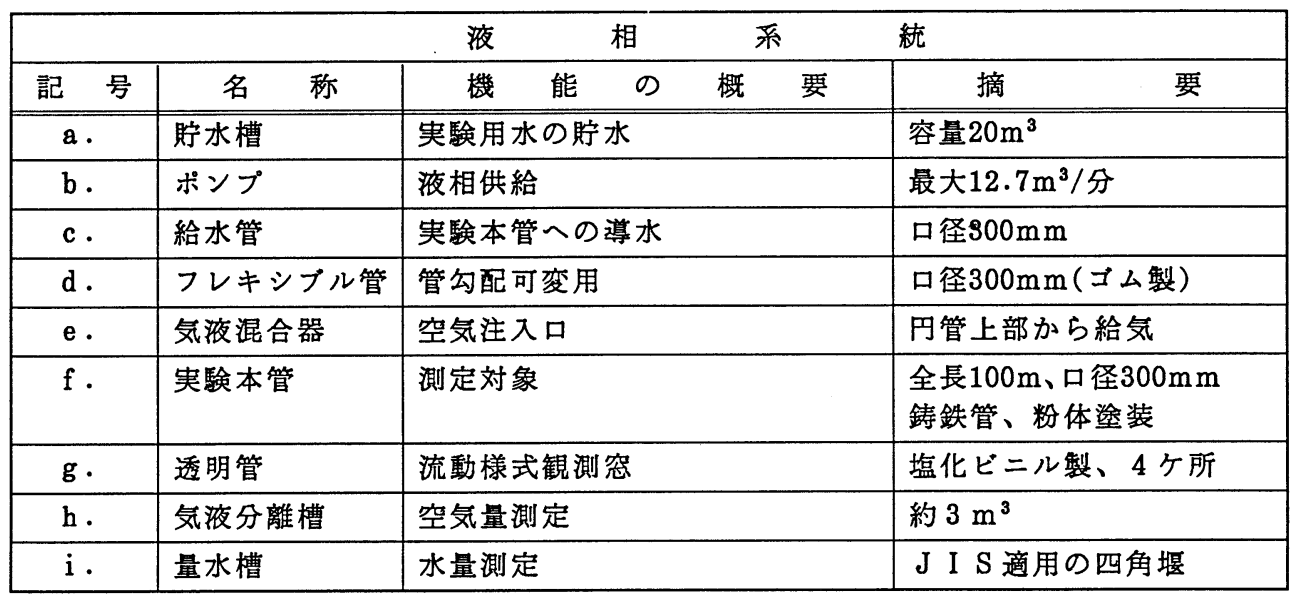

\begin{tabular}{|c|c|c|c|c|c|c|c|}
\hline . & & & 気 & 相 & & & 統 \\
\hline 記 号 & 名 & 称 & 機 & 能 & 概 & 要 & 摘 \\
\hline (1) & 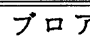 & & 気相供 & & & & $84 \mathrm{~m}^{3} /$ 分、 $0.3 \mathrm{~kg} / \mathrm{cm}^{2}$ \\
\hline (2) & 送気管 & & 混合器 & 送気 & & & 口径150mm \\
\hline
\end{tabular}

2. 2 実験条件の設定能力

2.2.1気相及び液相のみかけ流速

本実験装置では、液相供給量が最大 $12.7 \mathrm{~m}^{3} /$ 分 $\left(0.21 \mathrm{~m}^{3} / \mathrm{s}\right)$ であり、口径 $300 \mathrm{~mm}$ 円管(断面皘 $\left.0.0707 \mathrm{~m}^{2}\right)$ に対して、液相みかけ流速は最大 $3.0 \mathrm{~m} / \mathrm{s}$ に設定できる。気相供給量は $84 \mathrm{~m}^{3} /$ 分 $(1.41$ $\mathrm{m}^{3} / \mathrm{s}$ ) で、気相最大みかけ流速 $20 \mathrm{~m} / \mathrm{s}$ が設定可能である。 
また、それぞれの相の下限は、供給を停止することにより、みかけ流速 $0 \mathrm{~m} / \mathrm{s}$ ねでる。

\subsection{2 管勾配の設定範囲}

実験対象とする部分の管路勾配は、流れの方向に対して上り勾配及び下り勾配に変化させら れるような構造となっている。勾配変化は上流端部を上下させて行らが、その移動範囲は上下 各 $1.0 \mathrm{~m}$ 、したがって逆勾配および順勾配のそれぞれについて勾配 $10 \%$ まで設定可能である。 また、実験本管の途中から水・空気を供給できるように補助配管を設け、勾配設定範团を拡張 できるようにした。本実験では、実験本管を $30 \mathrm{~m}$ に短縮し、勾配 $30 \%$ まで観測・測定を行って いる。

2. 2. 3 観測・測定方法

(1) 流動様式の観測について

実験本管の一部を透明な合成樹脂で製作し、管路内部の流れを可視できる構造とした。可視 可能な観測部は、流れの方向に向かっての流動様式の変化を把握できるように全長 $100 \mathrm{~m}$ 場 合で 4 箇所に設置し、1 箇所当りの長さは $6.0 \mathrm{~m}$ である。また、観測を容易にするため、水に 色素を加え着色した。

(2) 圧力分布測定について

混相流の複雑な流動様式における圧力損失を調べるため圧力分布の測定を 4 箇所で行った。 圧力センサーには圧力変換器を使用し、その電気信号を記録紙に書かせてモニターしつつ、同 時にデジタル変換してコンピュータに取り込んだ。

(3) ボイド率測定について

水と空気とでは誘電率が異なる性質を利用し、測定断面における水と空気の割合を測定した。 原理としては容量式水面計と同じであるため、センサーを設置する壁面での水切を速くする工 夫をし、また測定実施前に検定を行った。

(4) 液相 (水) 流量

平均流量の測定はJIS規格に基づく四角堰で測定したが、給水管に流速計を設置し、実験対象 本管部での圧力変動によって流量変動が生じていないことを確認しながら測定を行った。

(5) 気相 (空気) 流量

気液分離槽において、管路を通過してきた空気を水と分離し、分離槽上部に設けた排気立孔 内部の空気流速を測定することにより、刻々吐き出されている空気量を測定した。従って、こ の測点で測定される空気量は、管路流動様式を反映したものとなり、間欠流であれば、激しい 変動を示し、層状流なら比較的に変動の少ない安定した值を示す。

また、気液混合器に供給している空気量は、混合器に入る前で測定した。

観測・測定法について概要をまとめ、Table 2 に示した。

Table 2 観測・測定方法

\begin{tabular}{|c|c|c|}
\hline 項 & 方 & 備 \\
\hline 流動様式 & 透明観測部の設置 & 1 籄所当り長さ $6.0 \mathrm{~m} 、 4$ 籄所設置 \\
\hline 圧力分布 & 压力 & 王力変換器 4 䇢所設置 \\
\hline ボイド率 & 静電容量式 & 4 箇所設置 \\
\hline 液相 (水) 流量 & $\begin{array}{l}\text { 流速測定 } \\
\text { 四角堰 }\end{array}$ & $\begin{array}{l}\text { 供給側 } \\
\text { 下流側の気液分離後 }\end{array}$ \\
\hline 気相 (空気) 流量 & $\begin{array}{l}\text { 流速測定 } \\
\text { 流速測定 }\end{array}$ & $\begin{array}{l}\text { 混合器に送り込んでいる量 } \\
\text { 気液分離槽での排出量 }\end{array}$ \\
\hline
\end{tabular}




\section{1 データ処理方法及び概要}

3. 1.1 計測及びデータ処理過程

計測から結果を得るまでの過程についてフローを示す。

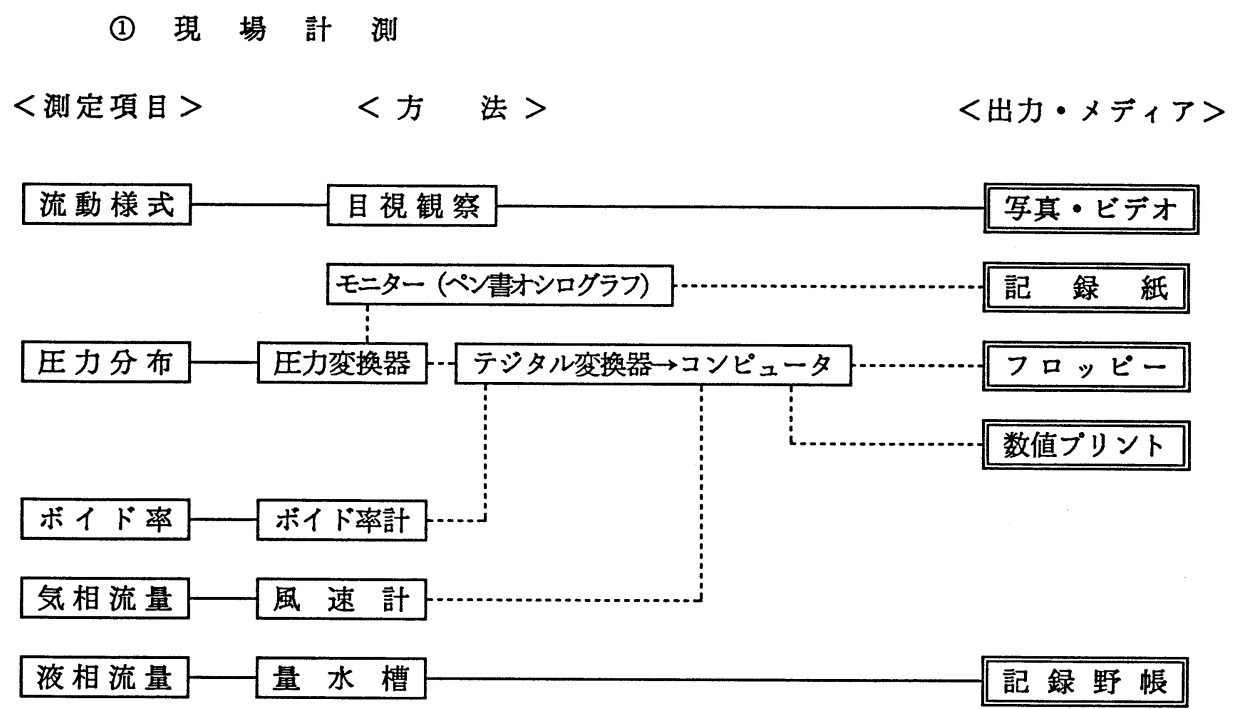

(2) データ処理

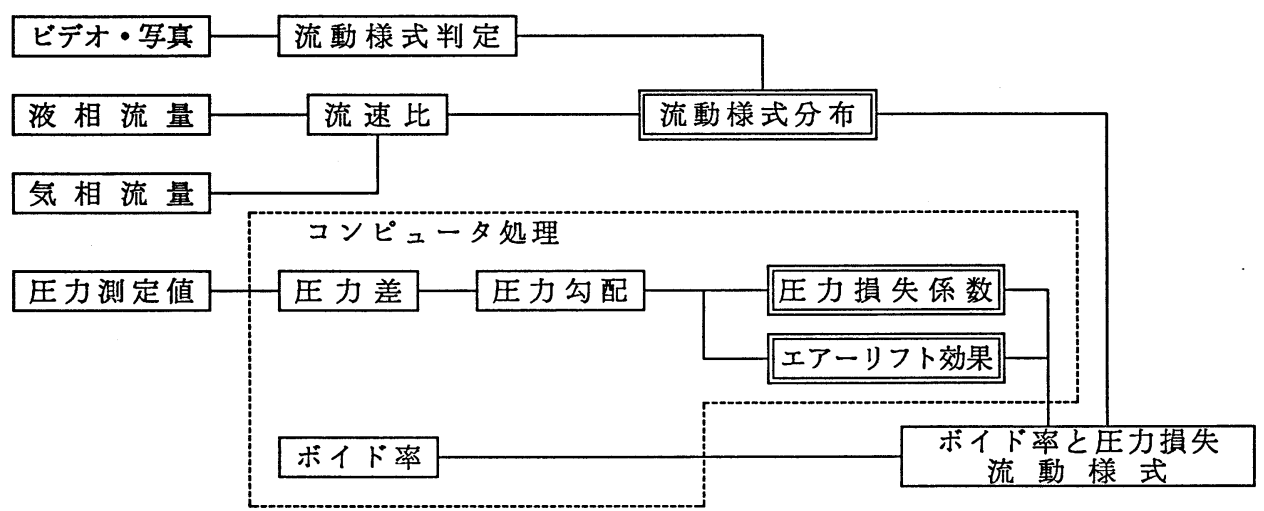

Fig. 2 計測及びデータ処理フロー図

\subsection{2 圧力損失の算出}

圧力変換器からの出力はFig. 3 に示すようなモニタ一記録するのと同時にアナログ/ディシ タル $(\mathrm{A} / \mathrm{D})$ 変換器を通して現場コンピュータに 1 秒間隔で読み込み、その值をすべて現場で ハードコピーするとともにフロッピーに記録した。

このデータをホストコンピュータに入力して各測定断面の平均圧力を求め、断面間の差を圧 力損失とした。 

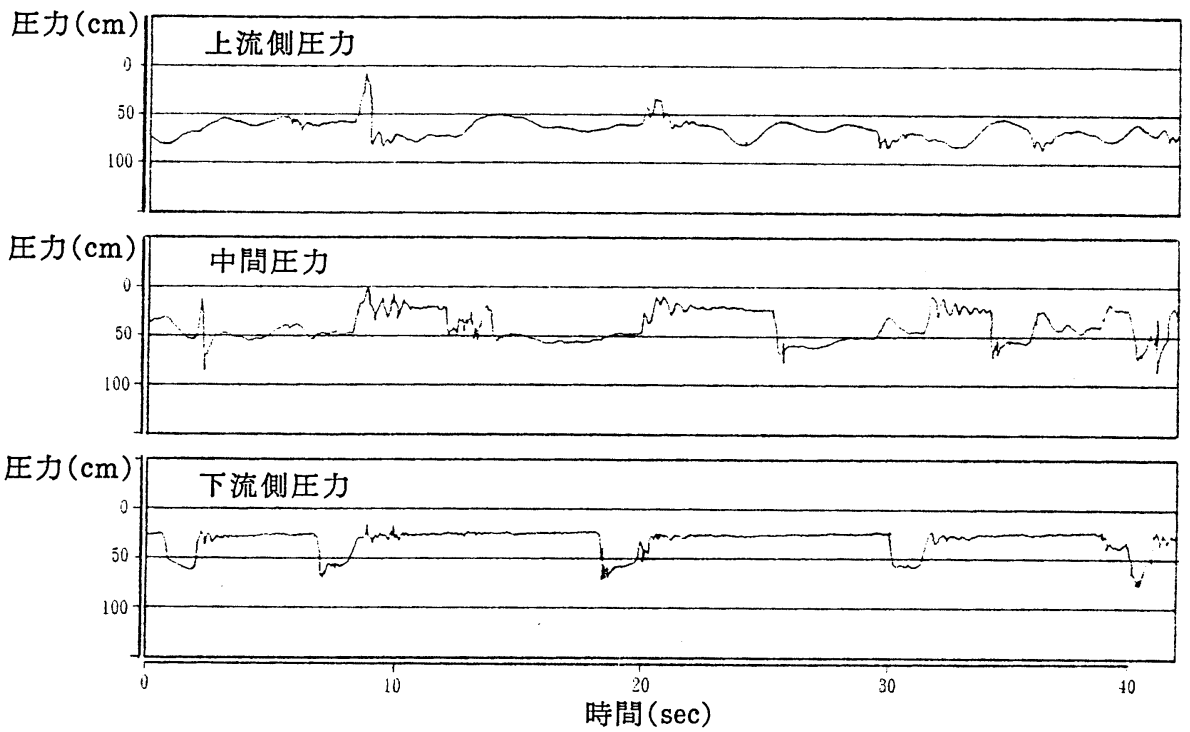

Fig. 3 モニター出力例

3. 1. 3 ボイド率の算出

ボイド率は気相の空間的な存在割合として考えた。流動様式によっては、相が不連続で時間 的に变化するため管断面の気相占有率を時間平均しボイド率とした。

\section{1.4 実験条件}

(1)管勾配及び管長

\begin{tabular}{|c|c|c|}
\hline 勾配 $(\%)$ & $\mathrm{O}($ 水平) & 順勾配 $5 \%$ \\
\hline 管長 $(\mathrm{m})$ & 100 及び 30 & 100 \\
\hline
\end{tabular}

\begin{tabular}{|c|c|c|c|c|c|c|}
\hline 逆勾配 (\%) & 1 & 2 & 5 & 10 & 15 & 30 \\
\hline 管長 $(\mathrm{m})$ & \multicolumn{3}{|c|}{100} & \multicolumn{3}{|c|}{30} \\
\hline
\end{tabular}

(2)実験条件

実験の状況にもよるが、施設能力最大の範囲で測定・実験を行った。概ね次の範囲である。 液相 :

$0.1 \sim 3.0 \mathrm{~m} / \mathrm{s}$

気相 :

$$
0.0 \sim 10.0 \mathrm{~m} / \mathrm{s}
$$

\section{2 流動様式}

3. 2.1 流動様式の判定

流動様式の判定は、次に示すような基準をもとに行った。

a) 分離流

1)層状流…気液が上下二層に分離してほ匡平滑な境界面をもつ流れ。

2) 波状流…気液境界が波状を呈する流れ、気相流速に伴って発生する小さな波も、この中に

(W) 入っている。

b)間欠流

1) プラグ流…流路上部に長い大気泡の存在する流れで、気液境界面の整合性が良く、小気泡

（P） を液相が取り込まない流れ。 
2) スラグ流…大気泡間の液体スラグ部分に多数の小気泡を含む流れで、気液境界面の整合性 （SL）が悪く小気泡を液相が取り込む流れ。

\begin{tabular}{|c|c|c|c|c|}
\hline 種別 & $\begin{array}{c}\text { 進行波先端 } \\
\text { 形状 }\end{array}$ & 液体スラグ中の空気 & 支配的な相 & $\begin{array}{l}\text { 両者の相対 } \\
\text { 速 }\end{array}$ \\
\hline プ ラ グ & 続 & 無 & $\begin{array}{l}\quad \text { 液相 } \\
\text { 水が空気を } \\
\text { 押す }\end{array}$ & 水 $\geqq$ 空気 \\
\hline スラグ & 不 連 続 & 有 & $\begin{array}{l}\quad \text { 気相 } \\
\text { 空気が水を } \\
\text { 押す }\end{array}$ & 空気 $>$ 水 \\
\hline
\end{tabular}

a）分離流

1)層状流

\begin{aligned} &$\Rightarrow$ 空気 \\ &$\Rightarrow$ 水 \\ & \hline\end{aligned}

2)波状流

$\therefore \quad \frac{\text { 空気 }}{\Rightarrow \text { 水 }}$

流動様式模式図

b ）間欠流

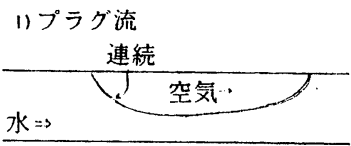

2)スラグ流

\begin{tabular}{|c|}
\hline 不連続 \\
\hline 気泡 $\because \frac{{ }^{3} \text { 空気 } \Rightarrow}{\text { 水 } \Rightarrow}$ \\
\hline
\end{tabular}

\section{3．2，1，1 水平管の流動様式}

水平管（長さ $100 \mathrm{~m}$ おび $30 \mathrm{~m} ）$ において水の見かけ速度 $V S L$ と空気の見かけ速度 $V_{S A}$ 変 化させ、その際の流動様式の状況を観測し、その結果をFig. 4 に示した。

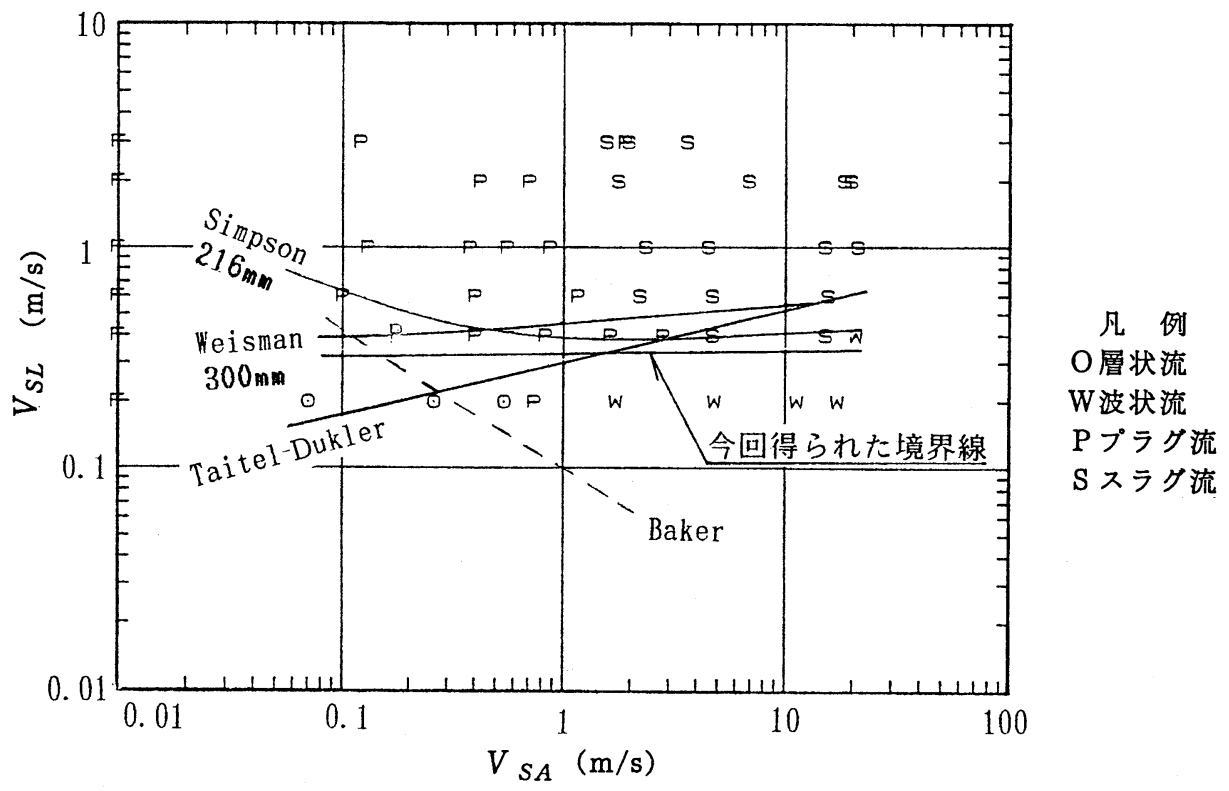

Fig. 4 流動様式分布

水平管 $D=300 \mathrm{~mm}$ 
なお、境界線付近になると間欠流といっても水が天井をで届くような波が現れる周期が非常 に長くなったり、管の距離が長くなると波が成長して行くことによる間欠流化等の現象が生じ てくる。

これより、V $V_{S L}$ が $0.3 \mathrm{~m} / \mathrm{s}$ 前後が分離流と間欠流の境界と考兄られる。

比較のためFig. 4 には、これまで発表された境界線図を入れてある。

流動様式は、V $V_{S A}$ の值に関わらず、 $V_{S L}$ が支配的な要因となっている。Baker線図 ては、V $V_{S A}$ が増大するに従い、V $V_{S L}$ が減っているが、それ以降の発表では概ね $V S L$ が支配的 といらものが多い。

一般に、大口径活ど間欠流となるV SL が大きくなる傾向であるが、その傾向は、Simpson の 発表ほど差はない結果となっている。

Weisman ${ }^{4}$ は、分離流と間欠流の境界式として、Taitel-Dukler式 ${ }^{5)}$ 参考に、次式を示してい る。

$$
V_{S A} /(g D)^{1 / 2}=0.25\left(V_{S A} / V_{S L}\right)^{1.1}
$$

この式を実験データと比較してみると大変よく適合しているとしている。

比較のため今回の実験データから、見かけ速度比 $\left(V_{S_{A}} / V_{S L}\right)$ 及び $V_{S_{A}} /(g D)^{1 / 2}$ の関係を Fig. 5 に示す。

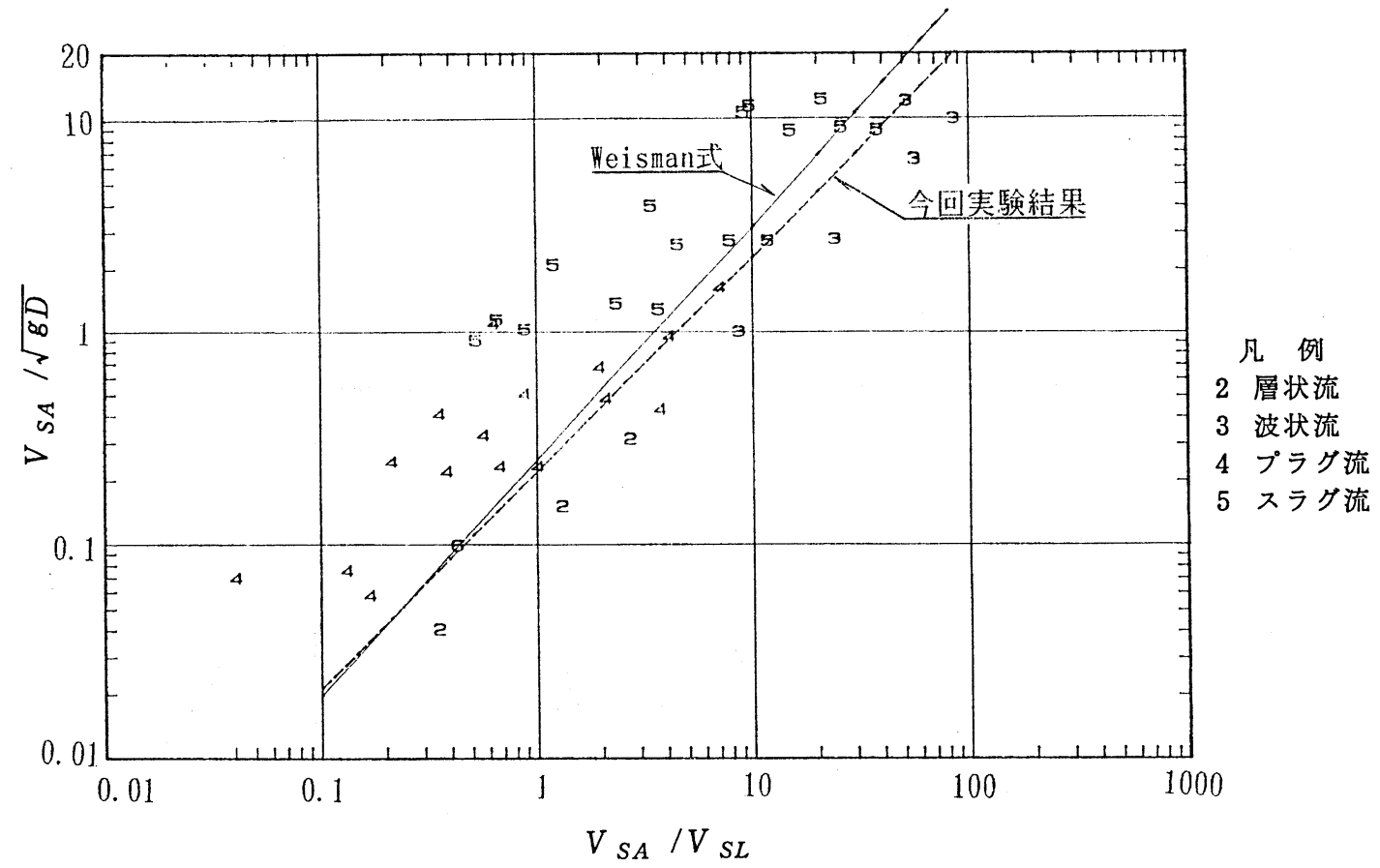

Fig. 5 分離流と間欠流の境界線

水平管

今回の実験でも、境界線は同じような傾向を示し、近似式は、

$$
V_{S A} /(g D)^{1 / 2}=0.2\left(V_{S A} / V_{S L}\right)
$$




$$
V_{s L}=0.2 \times(g D)^{1 / 2}
$$

と、V $S_{L L}$ が主因子といら結果となっている。

Weisman式を変形して見ると、

$$
V_{S L}=\sqrt[1,1]{0.25 \cdot V_{S A}^{0.1} \cdot(g D)^{1 / 2}}
$$

式(4)で、 $V_{S A}^{0.1}$ は、 $V_{S A}$ が0.1m/s $30 \mathrm{~m} / \mathrm{s}$ と大きく変化しても、0.79〜1.41と変動が少ない。 従って、Weisman式でも境界式は、 $V S_{S L}$ が定数に近い形となり、 $V S L$ と管径が主要支配因 子といらことになる。

以上、水平管の分離流と間欠流の境界は、Weisman式に近い結果が得られた。

\subsubsection{2 逆勾配管の流動様式}

逆勾配管において、入口より出口の方の位置が高いため、浮力を持つ空気はその高さ分に相 当するエネルギーを消費して、水平管より速く出口側に到達する。

$1 \%$ の実験結果をFig. 6、2\%をFig. 7、5\%をFig. 8 に示す。

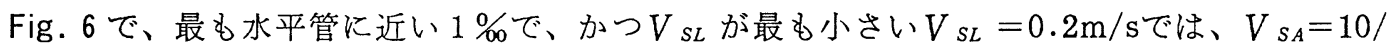
$\mathrm{m} / \mathrm{s}$ 以上の時を除いて、全部間欠流になっていることがわかる。また、Fig. 8 では、全測定が 間欠流になっている。

$1 \%$ 勾配は、10mの管延長で $1 \mathrm{~cm}$ 管底の上昇とその高低差は大変小さい。これだけ小さ い勾配の変化で流動様式が大きく影響を受けていることは、水平管の流動様式が非常に不安定 であることを示している。

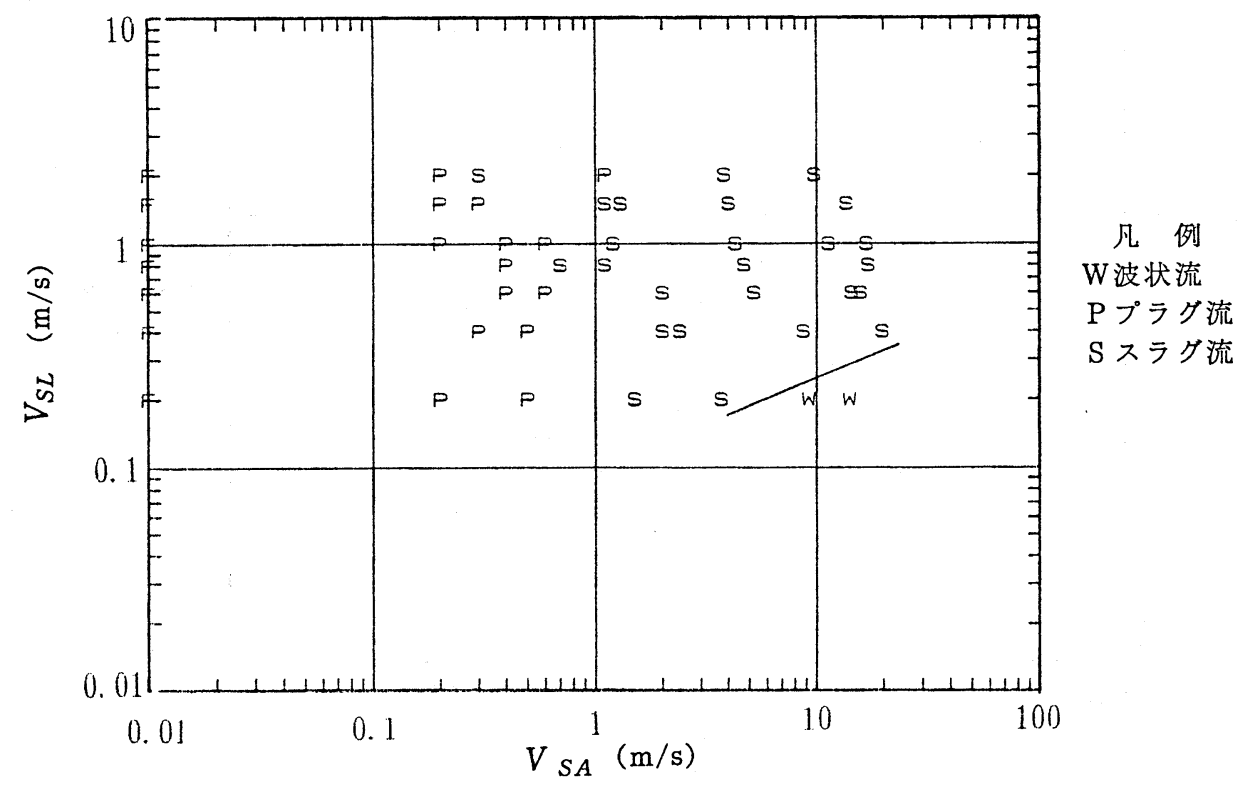

Fig. 6 流動様式分布

逆勾配管 $(1 \%)$ 


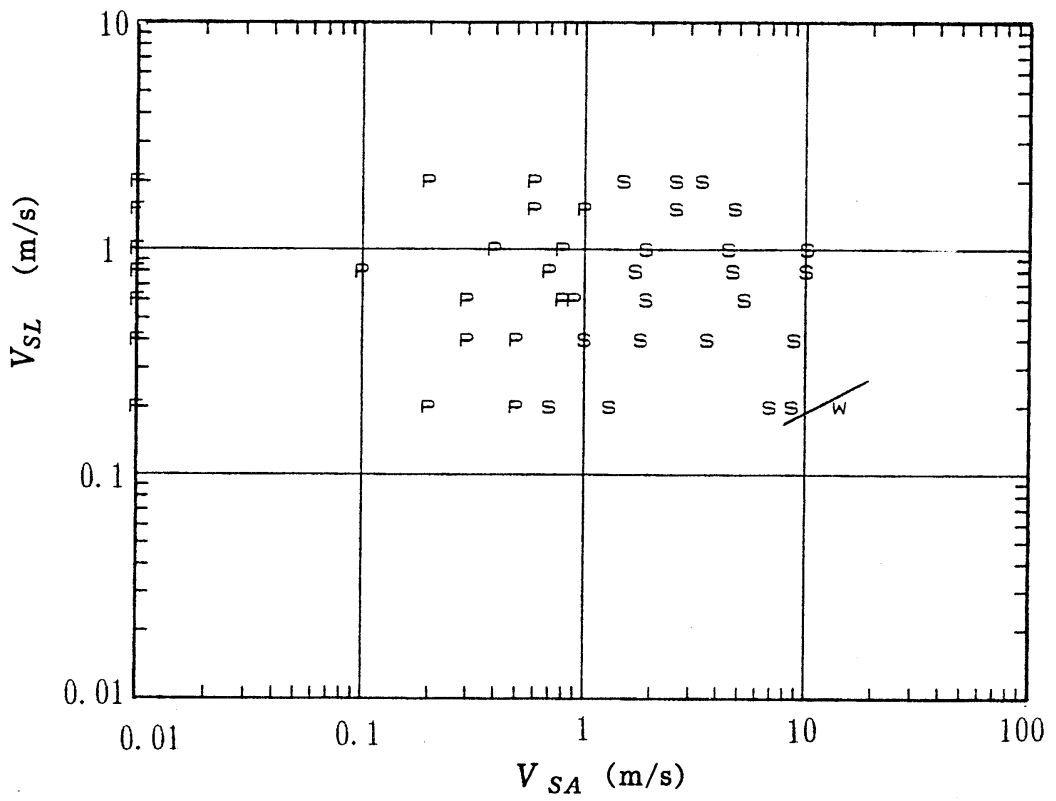

凡 例 W 波状流 $\mathrm{P}$ プラグ流 $\mathrm{S}$ スラグ流

Fig. 7 流動様式分布 逆勾配管 $(2 \%)$

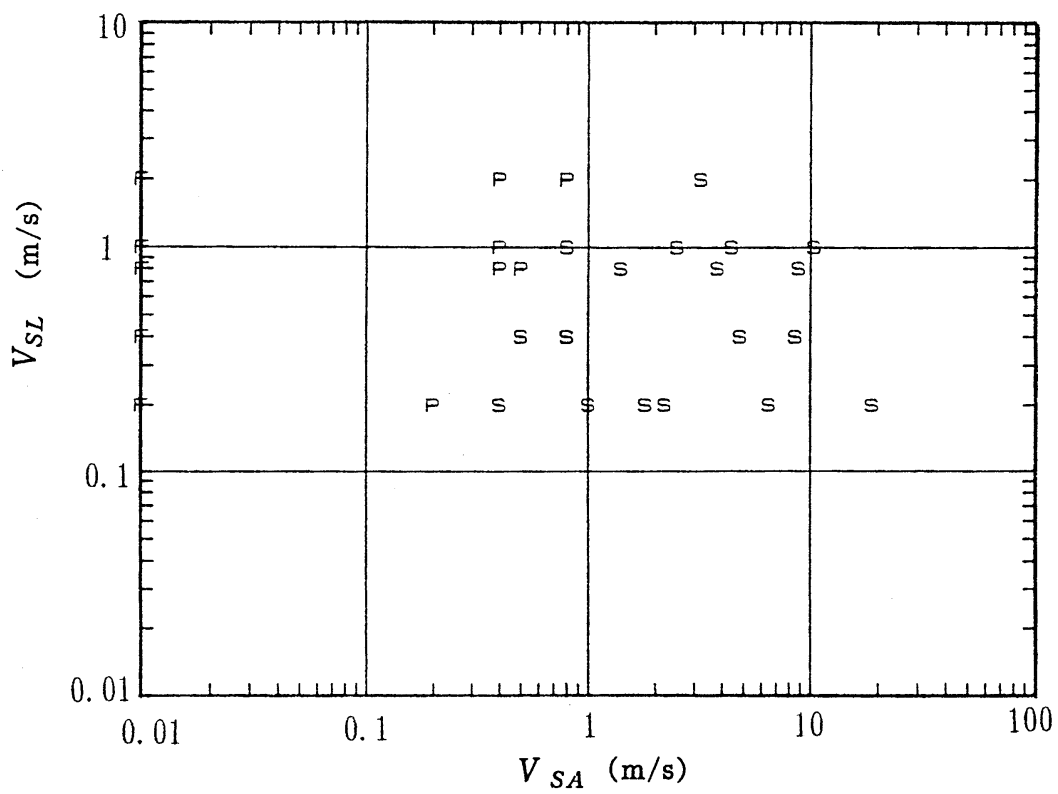

凡 例 $\mathrm{W}$ 波状流 $\mathrm{P}$ プラグ流 $\mathrm{S}$ スラグ流

Fig. 8 流動様式分布 逆勾配管 $(5 \%)$ 
勾配に敏感な理由としては、次のように考えられる。流下するにあたり摩擦ロスの少ない空 気は、少しの勾配変化により、浮力により大きな影響を受けるため、流速が大幅に違ってくる。 これが水流に影響し、流動様式が变化するものと考えられる。

実際の配管では、工場などを除き $\pm 1 / 1000$ 程度の水平状況に設置されることはほとんどない と考えられる。また、工場などにおいては、水平管であっても距離が短いため、両端の影響を 受け勾配のある管と同じような流動様式になると考えられる。

\subsubsection{3 順勾配管の流動様式}

順勾配管（下降流）においては、入口より出口の方が低いため、水はその分の落差を受け、 水平管より速く出口側に到達する。

$5 \%$ の順勾配管における実験結果をFig. 9 に示す。

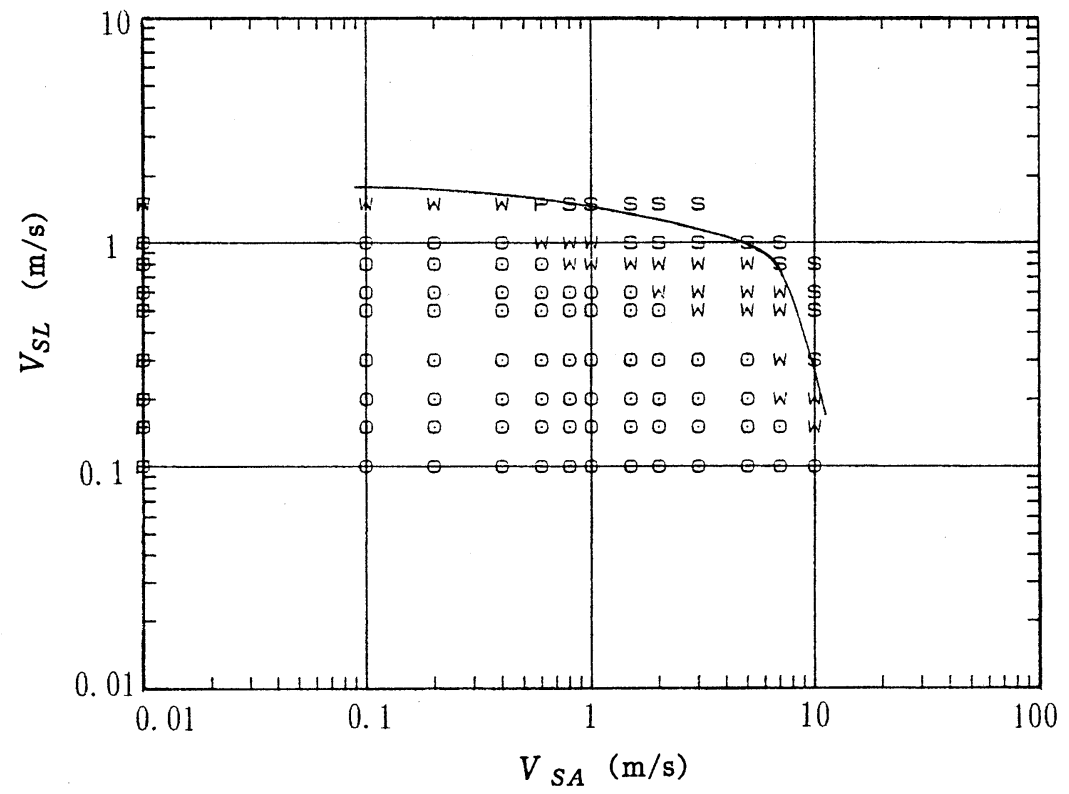

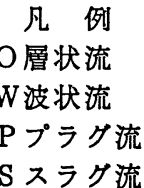

$\mathrm{S}$ スラグ流

Fig. 9 流動様式分布

順勾配管 $(5 \%)$

ここで、間欠流の分布が水平管に比較して相当高流速の方に後退していることがわかる。

空気見かけ流速が $1 \mathrm{~m} / \mathrm{s}$ 以下では $V S L$ が $1 \mathrm{~m}$ 以上をで分離流となっている。この流速は水平 管の場合の 3 倍程度である。この理由として、水の流速が上昇し、気液の境界面が下がり、ボ イド率が大きく、空気流による水のまきあげも少なくなるためと考えられる。

上昇流と同様、下降流でも勾配のちょっとした違いで、流動様式が全く異なってくる。

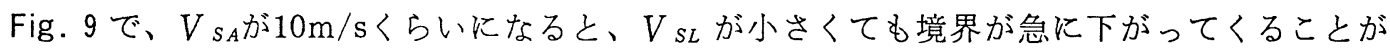
示されている。

\section{3 ボイド率}

ボイド率は、気液各見かけ流速において、実流速との関連で重要な要因である。但し、今回 の実験は、大半が間欠流で、不定期に満管になり、短時間経過の後、二相の流れに戻るという 状況で、データについても相当なバラッキが認められた。

3. 3.1 水平管のボイド率

Fig.10に、水平管のボイド率を示している。横軸はV $V_{S L}$ で、縦軸はV $S_{S A}$ でる。 


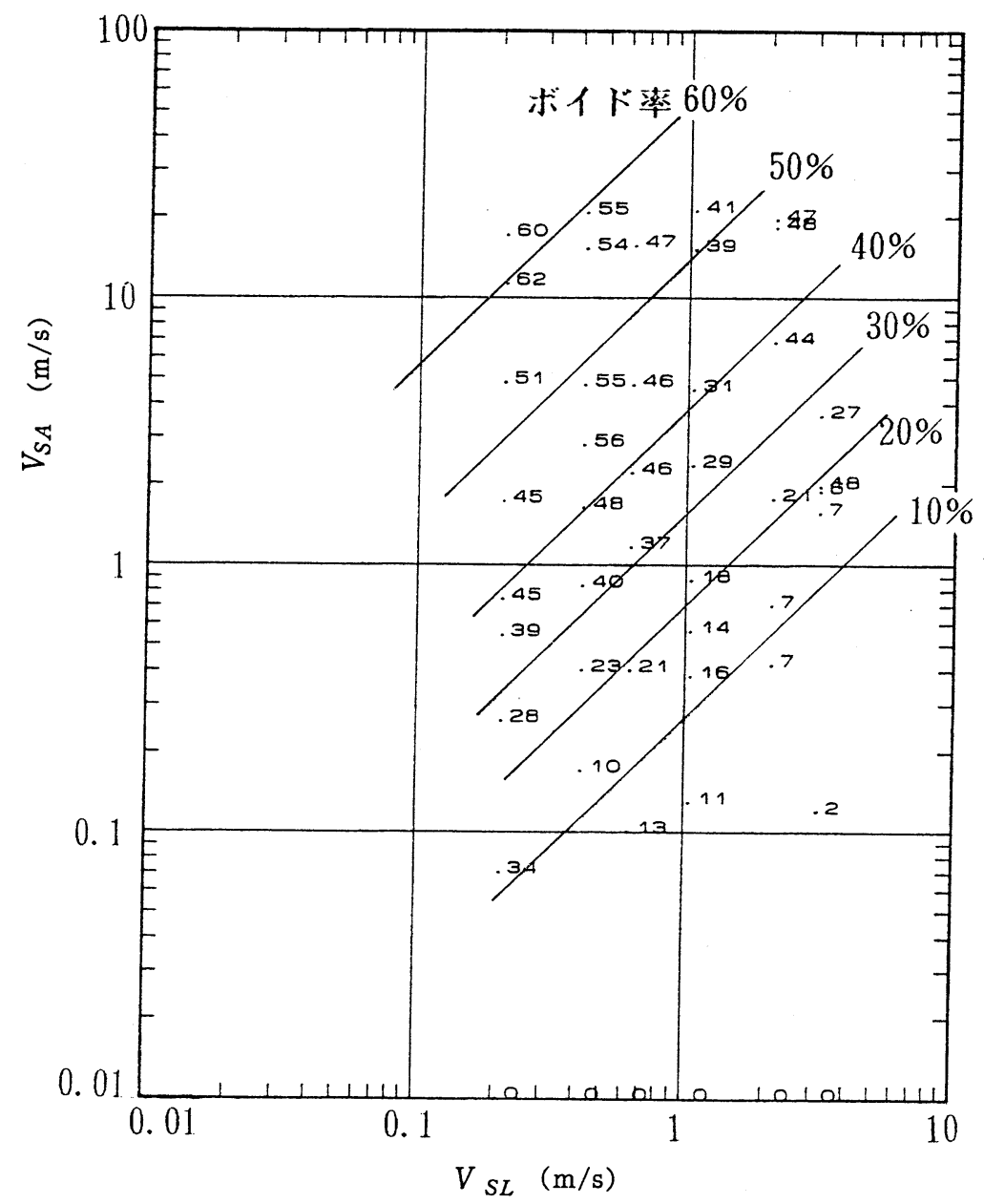

Fig.10 水・空気みかけ速度とボイド率 水平管 $D=300 \mathrm{~mm}$

Fig.10において、同じV $V_{S L}$ であるとすると、V $S_{A}$ が高い程ボイド率が増加している。 また、同じV $S_{S A}$ であば、V $S_{S L}$ が高いほどボイド率が低下している。

Fig.11は、同じ水平管のデータを用い、横軸がボイド率、縦軸は見かけ速度比 $\left(V_{S_{A}} / V_{S L}\right)$ として両者の関係を調べたものである。バラツキはあるが、概ね一本の曲線に代表できる。 このことは、同じ見かけ流速比であれば、その速度が大きくなっても、小さくなっても同じボ イド率になると想定されることを意味している。

これをもとに、平均的なボイド率をFig.10に示す。次に、各ボイド率における見かけ流速比か

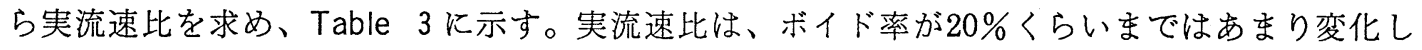
ないが、30\%以上になると急激に増加する。

また、成層流とした場合の各相の各ボイド率 における気液各相の流れやすさの比較を行った。 右図において、空気、水の流れを考える。流速 公式については、後述のManning式を考えた。

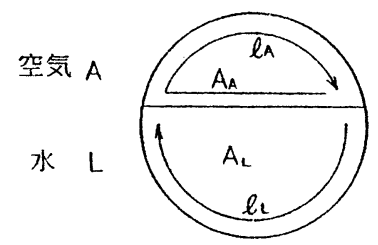




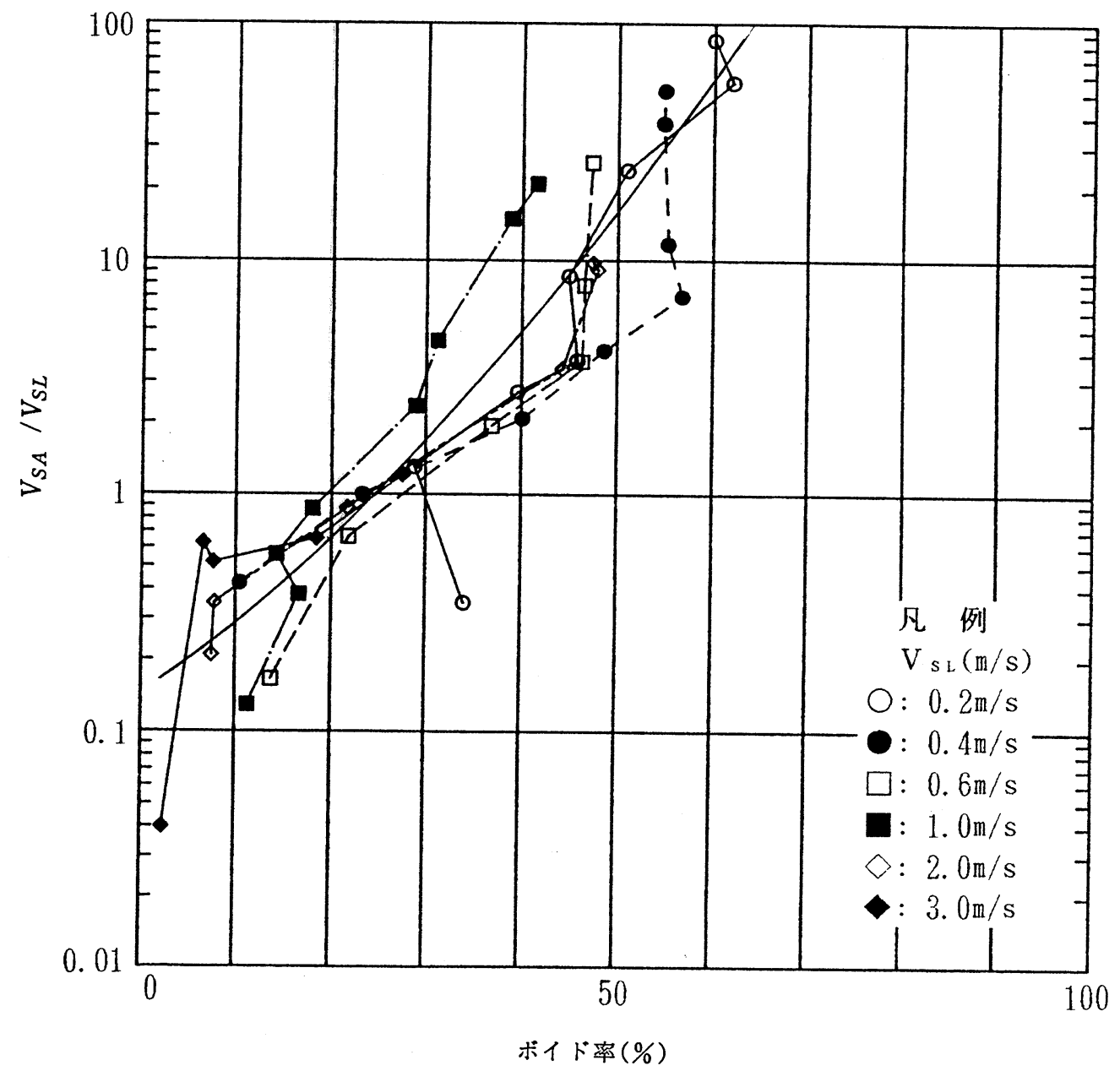

Fig. 11 水平管における $V_{S A} / V_{S L}$ とボイド率

Table 3 実流速比

\begin{tabular}{|c|c|c|c|c|c|c|c|}
\hline ボィド率 & $V_{S A} / V_{S L}$ & $V_{A} / V_{L}$ & $R_{A}$ & $R_{L}$ & $R_{A}^{2 / 3}$ & $R_{L}^{2 / 3}$ & $\begin{array}{l}V_{A} / R_{A} A^{2 / 3} \\
V_{L} / R_{L} / 3\end{array}$ \\
\hline 10 & $\begin{array}{r}0.30 \\
0.3: 1 \\
\end{array}$ & $\begin{array}{r}2.72 \\
3: 1.1 \\
\end{array}$ & 0.015 & 0.091 & 0.06 & 0.202 & 9.15 \\
\hline 20 & $\begin{array}{c}0.66 \\
0.66: 1 \\
\end{array}$ & $\begin{array}{c}2.64 \\
3.3: 1.25 \\
\end{array}$ & 0.024 & 0.090 & 0.083 & 0.202 & 6.43 \\
\hline 30 & $\begin{array}{c}1.70 \\
1.70: 1 \\
\end{array}$ & $\begin{array}{c}3.99 \\
5.7: 1.43 \\
\end{array}$ & 0.032 & 0.087 & 0.101 & 0.196 & 7.74 \\
\hline 40 & $\begin{array}{l}5.0 \\
5: 1 \\
\end{array}$ & $\begin{array}{c}7.49 \\
12.5: 1.67 \\
\end{array}$ & 0.039 & 0.082 & 0.115 & 0.189 & 12.30 \\
\hline 50 & $\begin{array}{l}15.0 \\
15: 1 \\
\end{array}$ & $\begin{array}{c}15 \\
30: 2 \\
\end{array}$ & 0.045 & 0.075 & 0.128 & 0.178 & 20.86 \\
\hline 60 & $\begin{array}{l}60.0 \\
60: 1\end{array}$ & $\begin{array}{c}40 \\
100: 2.5 \\
\end{array}$ & & & & & \\
\hline
\end{tabular}


ここで、空気については水と接している長さを流体辺長に考慮したが、水については空気と 接している長さを辺長に考慮していない。

空気の径心 $R_{A}=A_{A} / l_{A}$

水の径心 $R_{L}=A_{L} / l_{L}$

Manning式から、 $n \cdot\left(V / R^{2 / 3}\right)=I^{1 / 2}$

これより、 $R^{2 / 3}$ を流れやすさと考光、 $\left(V / R^{2 / 3}\right)$ について空気と水との比を求めTable 3 K 示す。断面積が小さい方が流れにくいため、ボイド率10\%で 9 程度を示し、20〜30\%でもあま り変化がないが、40\%を越えてから急に増加を示している。これより、ボイド率が40\%未満の 場合、水と空気は成層流と考㝋た場合の流れにくさの比を概ね保って流れていると考えられる。 しかし、同じ管を単相流で流下させた場合、同じ圧力差で空気は水の30倍程度の速度で流れる ことから、空気の圧力損失の相当程度が水の加速や攪找に使われていると考えられる。

3.3.2 逆勾配管のボイド率

Fig.12は、逆勾配 $5 \%$ \% V $S_{S L} 、 V_{S A}$ 及びボイド率の関係を示している。

Fig.13は、水平管と同様にして見かけ速度比とボイド率の相関を見たものである。

Fig.11と比較して、ボイド率が低い方向へ動いている。

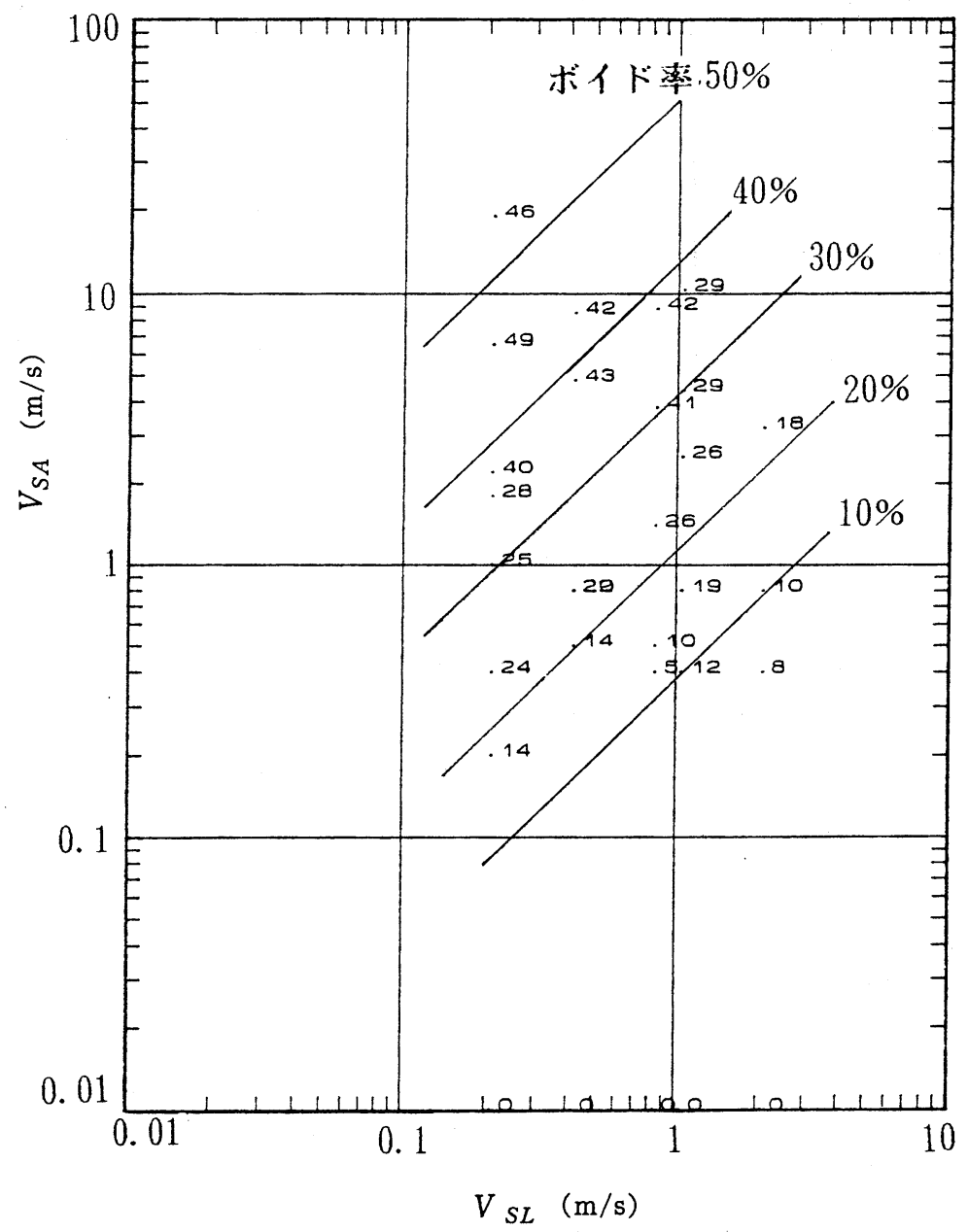

Fig. 12 水・空気みかけ速度とボイド率 逆勾配管 $5 \%$ 


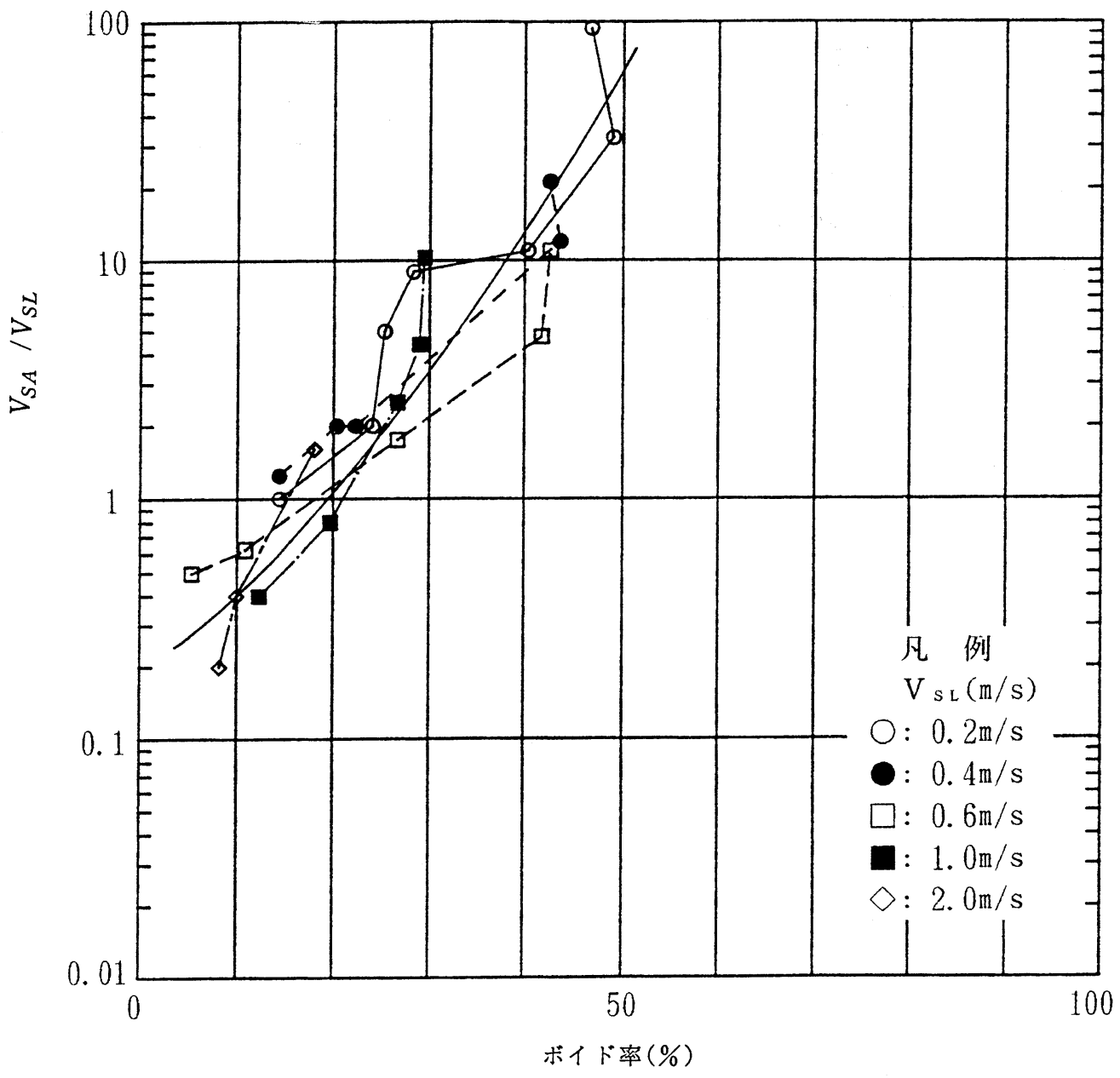

Fig. 13 逆勾配管 $(5 \%)$ における $V_{S A} / V_{S L}$ とボイド率

Table 4 に各ボイド率の見かけ流速比を示す。ボイド率の低い時はあまり差はないが、ボイ ド率の高い時、見かけ流速比は逆勾配で大幅に増加する。

同じ見かけ流速を考えた場合、逆勾配時には、水は上・下流の圧力差に逆勾配分の水位差が 圧損の合計となる。従って、空気を流下させる力が大きくなり、早く流れる。

Table 4 見かけ流速比 $\left(V_{S A} / V_{S L}\right)$

\begin{tabular}{|c|c|c|c|}
\hline ボイド率 & $\mathrm{A}(0 \%)$ & $\mathrm{B}(5 \% \mathrm{U} \mathrm{P})$ & $\mathrm{B} / \mathrm{A}$ \\
\hline 10 & 0.3 & 0.4 & 1.3 \\
\hline 20 & 0.66 & 1.3 & 2.0 \\
\hline 30 & 1.76 & 4.8 & 2.8 \\
\hline 40 & 5.0 & 16.0 & 3.2 \\
\hline 50 & 15.0 & 70.0 & 14.0 \\
\hline 60 & 60.0 & & \\
\hline
\end{tabular}


この結果、ボイド率は小さくなる。逆に、逆勾配時にもボイド率を保持するためには、その 分多量の空気を送る必要がでてくることとなる。

Table 4 より、例えばボイド率が $20 \% 、 V_{S L} 1 \mathrm{~m} / \mathrm{s}$ の流れを考えてみると、水平流ならV $V_{S A}$ は $0.66 \mathrm{~m} / \mathrm{s} 、 5 \%$ 逆勾配流であれば $V S_{S A}$ は $2.0 \mathrm{~m} / \mathrm{s}$ となり、逆勾配時に空気の見かけ速度が 3 倍 となっていることを意味している。実流速も同じく 3 倍となっている。

\section{3．３順勾配管のボイド率}

Fig. 14は、順勾配 $5 \%$ の時の $V S S 、 V S_{S A}$ 及びボイド率の関係を示している。水平流に比較し てボイド率が相当上昇している。

また、Fig.15はボイド率と見かけ速度比の関係を示している。水平管、逆勾配と異なり、回

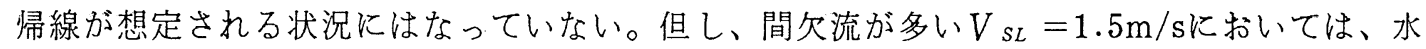
平管と同じような傾向を持っている。

Fig.14kおいて、おおまかな理解のため、等ボイド率線を考えてみた。一般に、V $V_{S A}$ が $1 \mathrm{~m} /$ s以下では、V $S_{A}$ に関係なく一定のボイド率となっている。このことは、液相断面が空気の流 れに関係なく、水の流れによって決まることを示している。

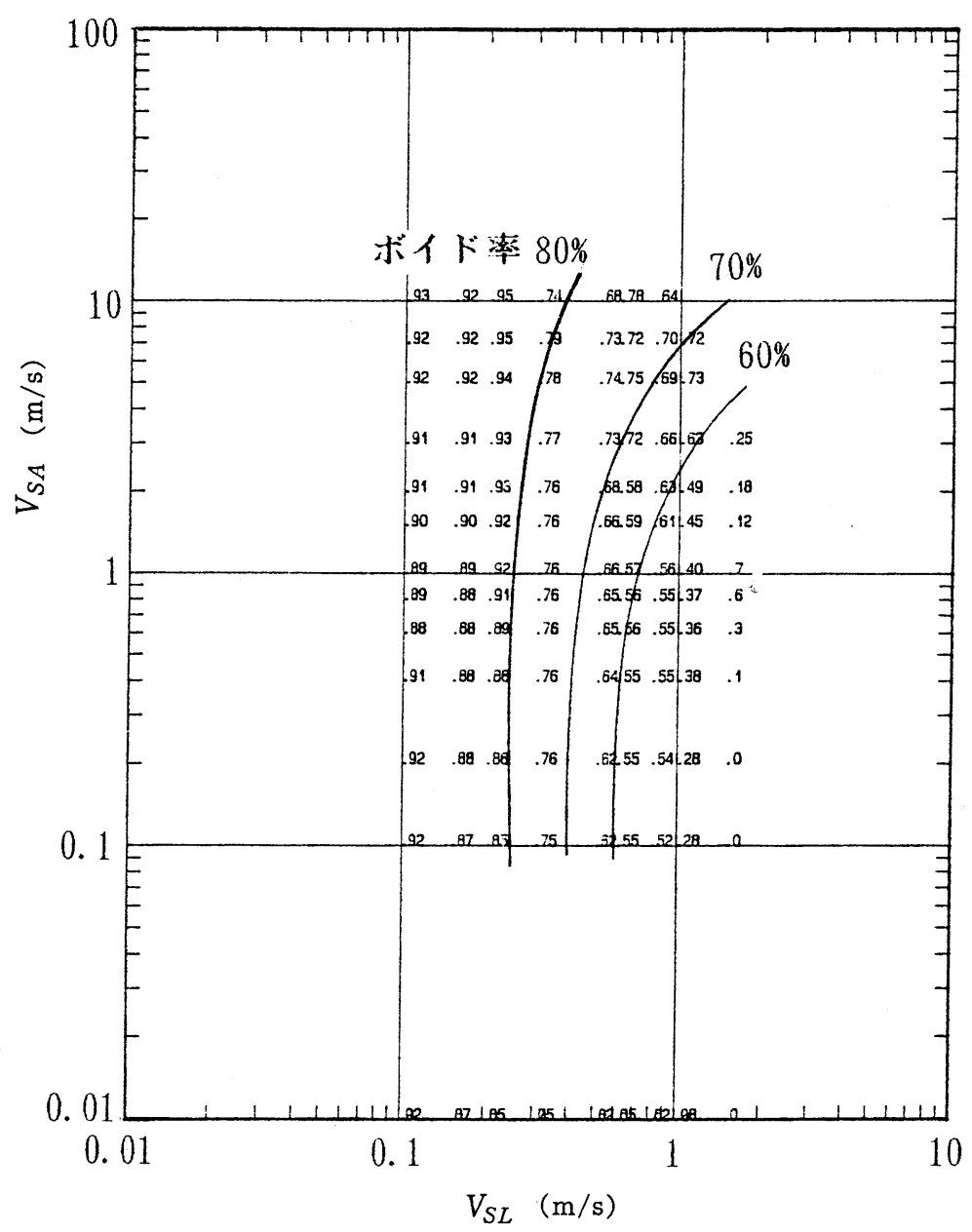

Fig. 14 水・空気みかけ速度とボイド率

順勾配管 $5 \%$ 


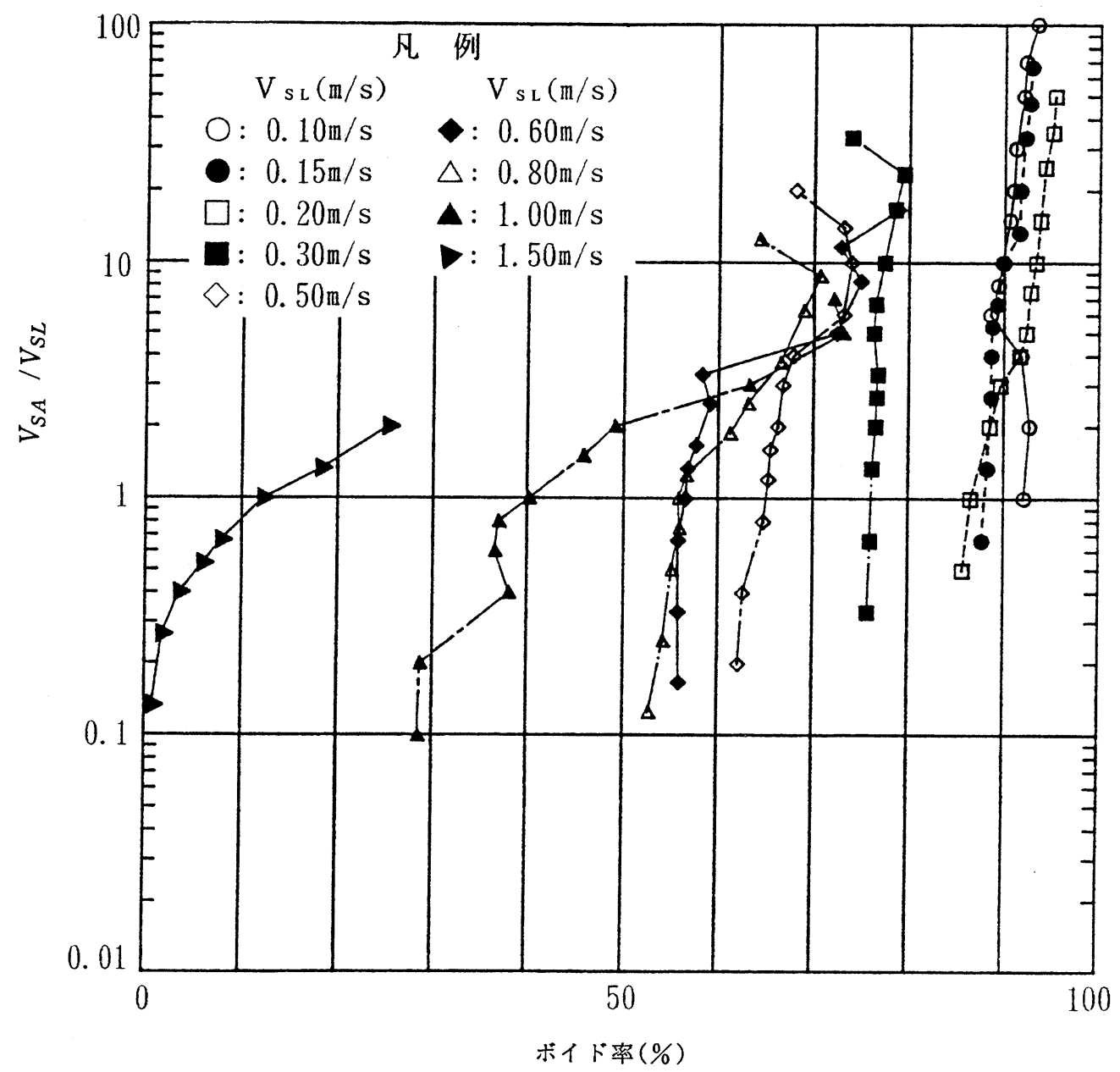

Fig. 15 順勾配管（ $5 \%$ \%) における $V_{S A} / V_{S L}$ とボイド率

また、V $s_{s L} 1 \mathrm{~m} / \mathrm{s}$ 以下とV $s_{s L} 1.5 \mathrm{~m} / \mathrm{s}$ とは全く異なった状況を示している。Fig.14のX軸下 の数値は各 $V s L$ の時の自然流下時のボイド率の式による計算值である。 $V S L$ が $1.5 \mathrm{~m} / \mathrm{s}$ のき は満管流になり、自然流下とはならない。

管の勾配によってどれくらいボイド率が違ってくるのかをグラフから求めると、V $S L 、 V S A$ ともに $1 \mathrm{~m} / \mathrm{s}$ とした時、 $5 \%$ 逆勾配は $18 \%$ 、水平流は $25 \% 、 5 \%$ 順勾配は $40 \%$ のボイド率を 示す。

また同じ40\%のボイド率を考光た場合、 $V s_{s L}=1 \mathrm{~m} / \mathrm{s}$ の時の $V s_{S A}$ は $5 \%$ 逆勾配では $16 \mathrm{~m} / \mathrm{s}$ (間欠流)、水平管では $4 \mathrm{~m} / \mathrm{s}$ (間欠流)、 $5 \%$ \% 順勾配では $1 \mathrm{~m} / \mathrm{s}$ （波状流）と何倍も違ってくる ことがわかる。

\section{4 圧力損失}

3. 4. 1 満管流の圧力損失

今回の二相流圧力損失実験を検討する上で重要となる水頭損失について、満管流の状況でど らなっているかを調べた。 


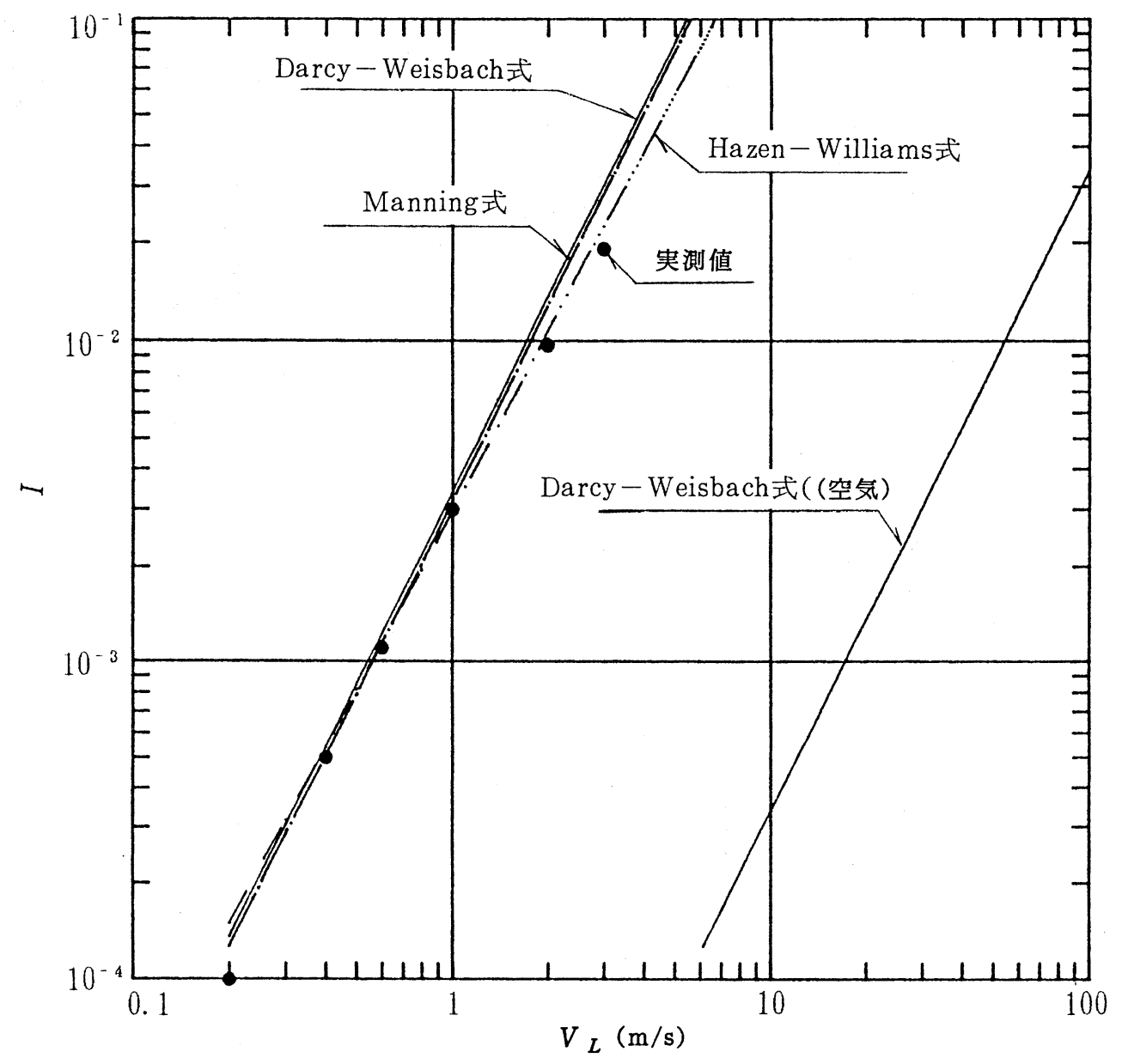

Fig. 16 満流時の圧力損失水頭 $(\phi 300 \mathrm{~mm})$

\subsubsection{1 水の場合}

Fig.16亿満管時水平流の $V_{S L} \quad\left(=V_{L}\right)$ 及び圧力損失の実験結果を示す。

本実験で使用されたパイプは、内面を粉体塗装したダクタイル鋳鉄管であり、一本あたり延 長は $6.0 \mathrm{~m}$ 、接合方法は一般 $\mathrm{A}$ 型である。延長 $100 \mathrm{~m}$ のち、途中 4 力所に $6 \mathrm{~m}$ ほ ぞの透明塩化 ビニル管（延長 $1 \mathrm{~m}$ もを 6 本フランジ接合したもの）を使用している。

また、勾配の大きい場合については、延長 $30 \mathrm{~m} の$ 管で実験を行なった。

・流速公式との比較

a.Hazen-Williams式

満管流状態の流れについてょく用いられているHazen-Williams式(H-W式)は、

$$
V=0.84935 \times C_{H} \times R^{0.63} \times I^{0.54}
$$

ここで、 $V \cdots$ 流速 $(\mathrm{m} / \mathrm{s}), R \cdots$ 径深 $(\mathrm{m}) 、 C_{H} \cdots$ 流速係数、 $I \cdots$ 勾配 流速係数 $C_{H}$ は次のような值となっている。 


$$
\begin{array}{cr}
\text { 鋳鉄 鋼（新） } & 130 \sim 140 \\
\text { "I（古） } & 60 \sim 100 \\
\text { コンクリート } & 120 \sim 140
\end{array}
$$

ここでは $C_{H}$ を140として計算してみた。

\section{b.Manning式}

開水路で一般に使用されているManning式の場合

$$
V=\frac{1}{n} R^{2 / 3} \cdot I^{1 / 2}
$$

ここで、 $n \cdots$ 粗度係数、 $R \cdots$ 径深 : 流体面積/流体辺長、 $I \cdots$ 勾配

$n$ は、滑らかな場合0.01〜0.015とされるが、ここでは $n=0.01$ とした。

c. Darcy-Weisbach式

同式は、あらゆる流体について基本となる式で

$$
I=\frac{1}{1000} \cdot \lambda \frac{1}{\mathrm{~d}} \cdot \frac{V^{2}}{2 g} \gamma
$$

$\lambda:$ 管摩擦係数、 $d:$ 管径 $(\mathrm{m}) 、 \gamma$ : 比重量 $\left(\mathrm{kg} / \mathrm{m}^{3}\right) 、 V:$ 流速 $(\mathrm{m} / \mathrm{s})$ これより、

$$
V=\sqrt{\frac{2 g \times d \times I \times 1000}{r \times \lambda}}
$$

入は、レイノルズ数及び管壁の粗さとの関数である。

$\lambda$ を求めるため、Moody線図を使用した。 $\varepsilon / d$ は、眓より0.001とした。レイノルズ数は、 $10^{4} \sim 10^{6}$ の範团であり、入は0.02〜0.024となった。

Fig. 16に実測值と流速公式から算出したグラフを示す。実測值と計算值は、おおむね一致す る。 $\mathrm{H}-\mathrm{W}$ 式、Manning式とは、 $V_{L}$ が $0.5 \mathrm{~m} / \mathrm{s} \sim 1 \mathrm{~m} / \mathrm{s}$ の範囲では殆ど同じであり、それより

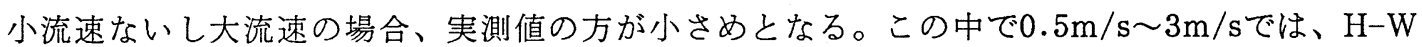
式が最も近接している。0.2m/s 0.4m/sでは、Manning式が最も近いが、ここの部分のデー タは小さい值であり不安定である。

3.4.1.2 空気の場合

実測值はなく、Darcy-Weisbach(7)式で計算した。ここで、 $\lambda=0.02 、 \gamma=1.2 \mathrm{~kg} / \mathrm{m}^{3}$ とし、 $I=4 \times 10^{-6} \cdot V^{2}{ }_{A}$ となった。

空気の圧力損失は、同じ速度の水の約 $1 / 1000$ である。 $\phi 300 \mathrm{~mm}$ 管で、圧力勾配 $1 / 1000$ 管を計 算してみると、

$$
\begin{aligned}
& \text { 空気 } V=15.7 \mathrm{~m} / \mathrm{s} \text { 、 } \\
& \text { 水 } \quad V=0.54 \mathrm{~m} / \mathrm{s}
\end{aligned}
$$

となり、空気は水の約30倍となる。

\subsection{2 水平管の圧力損失}

Fig.17は、100m水平管において $V_{S L}$ の各段階での $V_{S A}$ と圧力勾配の関係を示したものであ る。同じ $V_{S L}$ で見たとき、 $V_{S A}$ が $V_{S L}$ より小さい場合は $V_{S A}$ の増加に伴う圧力損失の上昇は 少ない。 $V_{S A}$ がそれ以上になった時、 $V_{S A}$ の倍率の $1 / 2$ 乗程度で圧力損失が上昇する。しかし、 単相流の場合、流速上昇の倍率の 2 乗で圧力損失が増大することに比較すると大変緩やかである。 


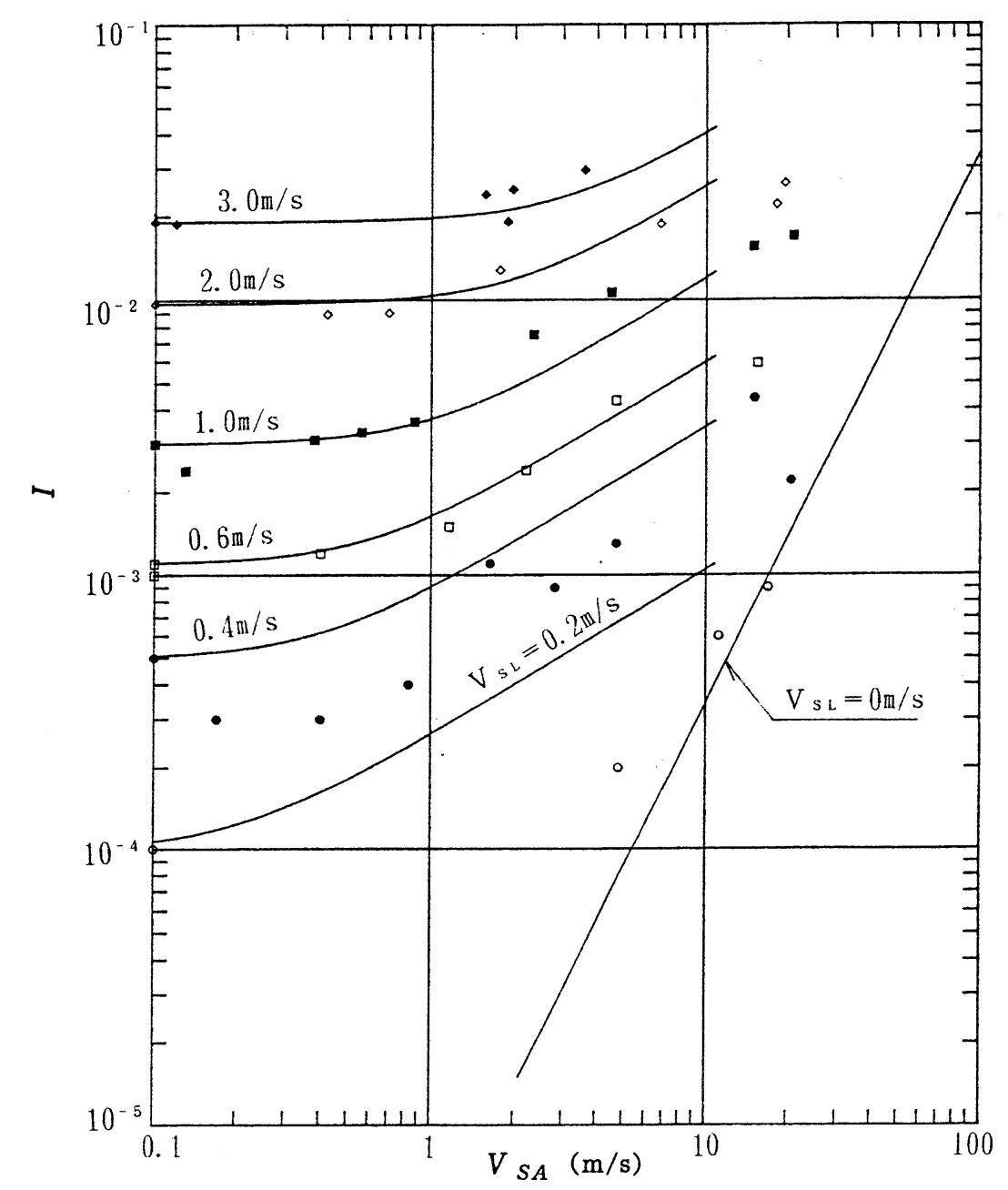

Fig. 17 水平管における空気みかけ速度 $V_{S A}$ と損失水頭 $I$

Fig.19は、Simpsonらによる $\phi 216 \mathrm{~mm}$ の実験結果の一部である。この実験は、延長 $16 \mathrm{~m}$ 管 を使用している。Fig.17と同様、 $V_{S A}$ の倍率に比較して圧力損失はそれほど増加していない。

Fig.17の一番右側の線は、空気のみの流れをDarcy-Weisbach式にあてはめて、圧力損失を計 算したものである。これより右側に行くことはないので、 $V_{S A}$ がこの線に近づくにつれ、圧力 損失が $V_{S A}$ の倍率の 2 乗に近くなっていくと思われる。

Fig.18は、水と空気の見かけ速度の和 $\left(V_{S L}+V_{S A}\right)$ と圧力損失の関係を調べたものである。 圧力損失は、水だけ流れる場合と空気だけ流れる場合の範囲内におさまると考えられる。

実測値を代表する回帰式として各種のものを検討した。

現時点では、次式が得られている。

$$
I_{M}=I_{L O}\left\{\frac{\left(V^{2} S_{S L}+V^{2} S_{A}\right)}{V_{S L}^{2}}\right\}^{0.3}=I_{L O}\left(1+\frac{V^{2} S_{A}}{V^{2}{ }_{S L}}\right)^{0.3}
$$

$I_{M} \quad \cdots$ 圧力損失勾配

$I_{L O} \quad \cdots V_{S A}=0 \mathrm{~m} / \mathrm{s}$ のをきの $I_{M}$ 
ここで、 $I_{L O}$ は $V_{S A}=0 \mathrm{~m} / \mathrm{s}$ 時、つまり水の満管流時の圧力損失勾配である。

$V_{S A}$ が、 $0 \mathrm{~m} / \mathrm{s}$ から次第に増加していった時を考える。 $V_{S L}$ に比較して $V_{S A}$ が小さい時、圧 力損失の大きい水流に空気が混じる程度であり、圧力損失は増加しないと考えられる。むしろ、 水流が壁に接する面積が多少減って、流れやすくなるくらいではないかと考えられる。

$V_{S A}$ が、もっと大きくなった時、全体の流速が上がり、空気流に近づいていくため、圧力損 失の増加が大きくなるものと考えられる。この意味で、式(9)は $V_{S A} / V_{S L}$ の高い時はあては まらない。

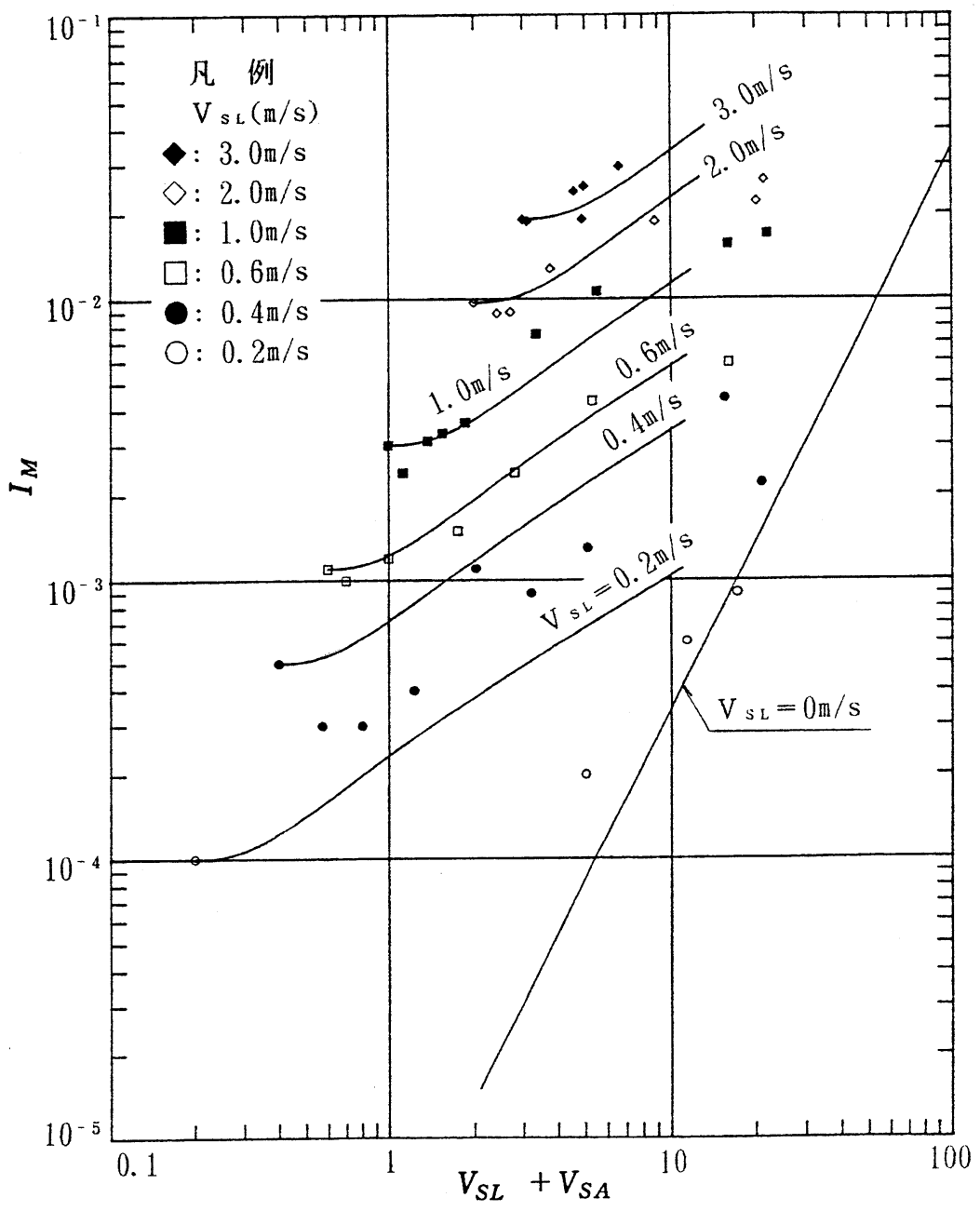

Fig. 18 水平管における $\left(V_{S A}+V_{S L}\right)$ と損失水頭 $I_{M}$

Fig.17,18の圧力損失測定データは相当バラついており、これは空気の塊の通過時の急変に よるものと考えられる。実測值と実験式は、 $V_{S L}=0.6 \mathrm{~m} / \mathrm{s}$ 以上では近くなっているが、それ 以下では離れる傾向にある。この部分は圧力損失が非常に小さく、測定が難しいことによると 思われる。式(9)は、Fig.17,18k実線で示されている。 


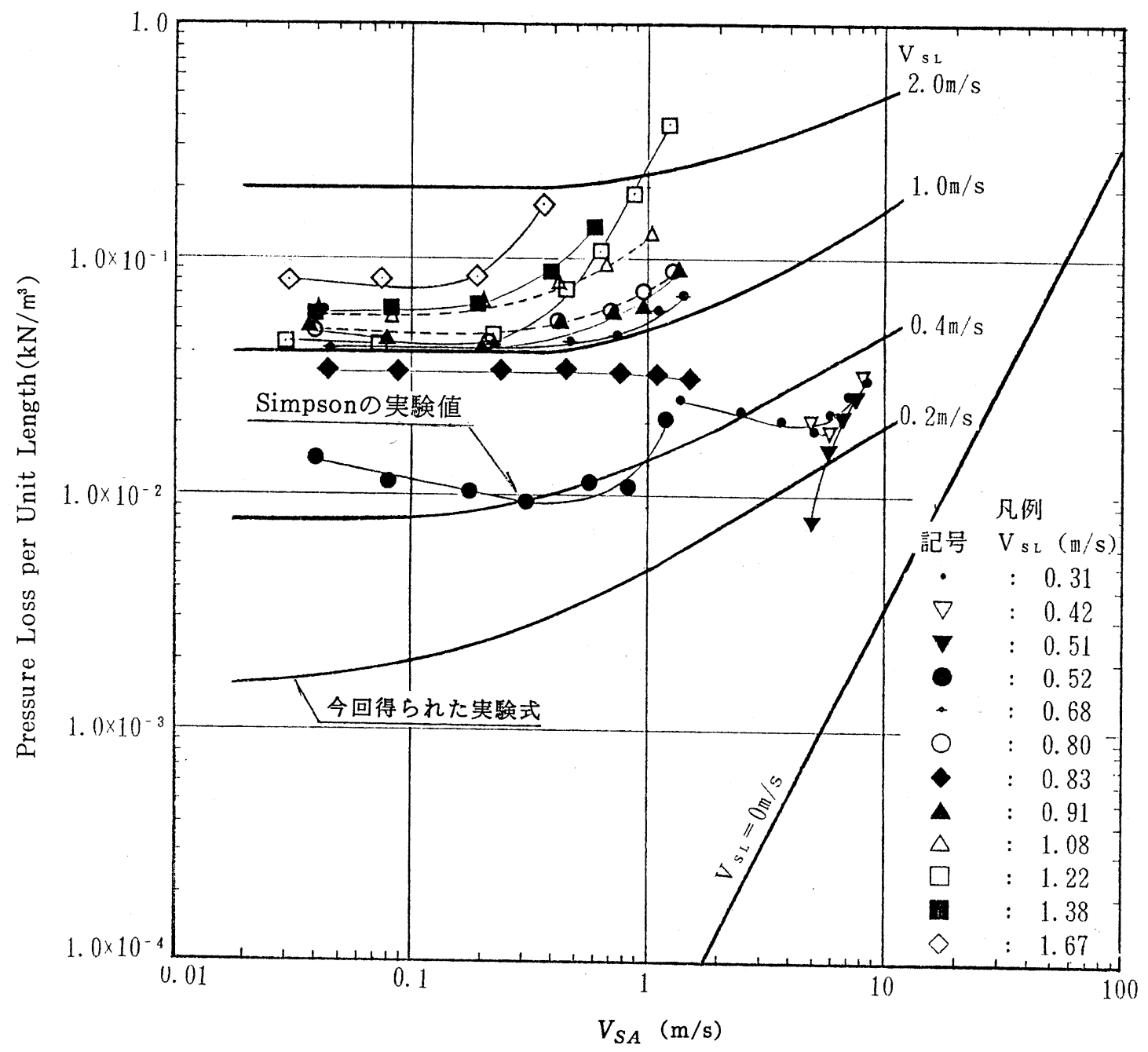

Fig. 19 水平管における空気みかけ速度 $V_{S A}$ と損失水頭 (Simpson実験 : $D=216 \mathrm{~mm}$ )

式(9)を前提とすると、見かけ速度比（ $\left.V_{S A} / V_{S L}\right)$ が一定の場合、水と空気の見かけ速度 の合計 $\left(V_{S L}+V_{S A}\right)$ の 2 乗は、おおむね圧力損失に比例することとなる。

$$
\begin{aligned}
& I_{M 1}=I_{L O 1}\left(1+\frac{V^{2} S A 1}{V_{S L 1}^{2}}\right)^{0.3} \\
& I_{M 2}=I_{L O 2}\left(1+\frac{V_{S A 2}^{2}}{V_{S L 2}^{2}}\right)^{0.3}
\end{aligned}
$$




$$
\begin{aligned}
& \frac{V_{S A 1}}{V_{S L 1}}=\frac{V_{S A 2}}{V_{S L 2}} \text { とすると } \\
& \frac{I_{M 2}}{I_{M 1}}=\frac{I_{L O 2}\left(1+\frac{V^{2} V_{S A 2}^{2}}{V_{S L 2}^{2}}\right)^{0.3}}{I_{L O 1}\left(1+\frac{V^{2}{ }_{S A 1}}{V_{S L 1}^{2}}\right)^{0.3}}=\frac{I_{L O 2}}{I_{L O 1}} \\
& I_{L O 2} \fallingdotseq I_{L O 1} \times\left(\frac{V_{S L 2}}{V_{S L 1}}\right)^{2} \quad \text { であるので、 } \\
& \frac{I_{M 2}}{I_{M 1}} \fallingdotseq \frac{I_{L O 1} \times\left(\frac{V_{S L 2}}{V_{S L 1}}\right)^{2}}{I_{L O 1}}=\left(\frac{V_{S L 2}}{V_{S L 1}}\right)^{2} \\
& =\left\{\frac{V_{S L 2}\left(1+\frac{V_{S A 2}}{V_{S L 2}}\right)}{V_{S L 1}\left(1+\frac{V_{S A 1}}{V_{S L 1}}\right)}\right\}^{2} \\
& =\left(\frac{V_{S L 2}+V_{S A 2}}{V_{S L 1}+V_{S A 1}}\right)^{2}
\end{aligned}
$$

ボイド率に括いては、見か㚈速度比（ $\left.V_{S A} / V_{S L}\right)$ が一定であればボイド率も一定になる 関係が得られている。

この結果、次のように考光られる。見かけ速度比( $\left.V_{S A} / V_{S L}\right)$ が一定のまま全体の流速が増 加していった場合、ボイド率が一定のため、空気も水も実流速が同様に増加していく。このた め、圧力損失む流速增の 2 乗炕打むれ比例する。

今回の実験では、空気側の圧力損失が単相流に比較して非常に大きくなっている。この圧力 損失は、水の加速と乱れ使われているが、この割合も一定であると考光られる。

次に、Lockhart-Martinelli ${ }^{6)}$ 相関との関係について調べた。現在、実用的に二相流の圧力損 失を求める方法としては、二相流中の摩擦損失が、二相流の液相成分だけが流れた場合、ある いは全量が液相として流れた場合の何倍になるかという表示方法が利用されている。そのうら、 水平管に拈ける二成分系流れの測定值をもとに構成されているLockhart-Martinelli ${ }^{6}$ の方法が よく受け入れられている。この值をTable 5 と示す。この圧力損失と実測值及び式(9) との比 較をFig. 20,21亿示す。 $V_{S A}$ が低いときは当然一致するが、 $V_{S A}$ が大きくなるにつれ、L-M相 関によるものが高くなり、 $V_{S A} 10 \mathrm{~m} / \mathrm{s} \sim 20 \mathrm{~m} / \mathrm{s} て ゙$ 約 2 倍となる。 


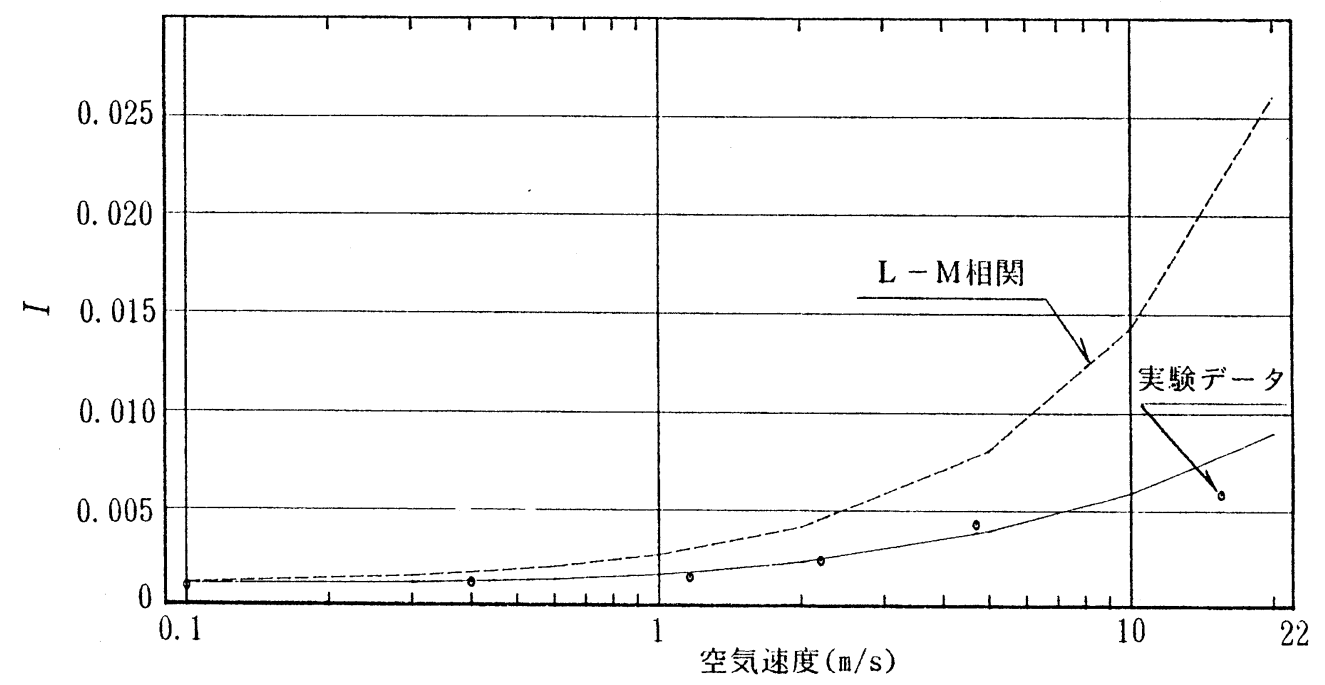

Fig.20圧損の比較（水速度 $V_{L}=0.6 \mathrm{~m} / \mathrm{s}$ )

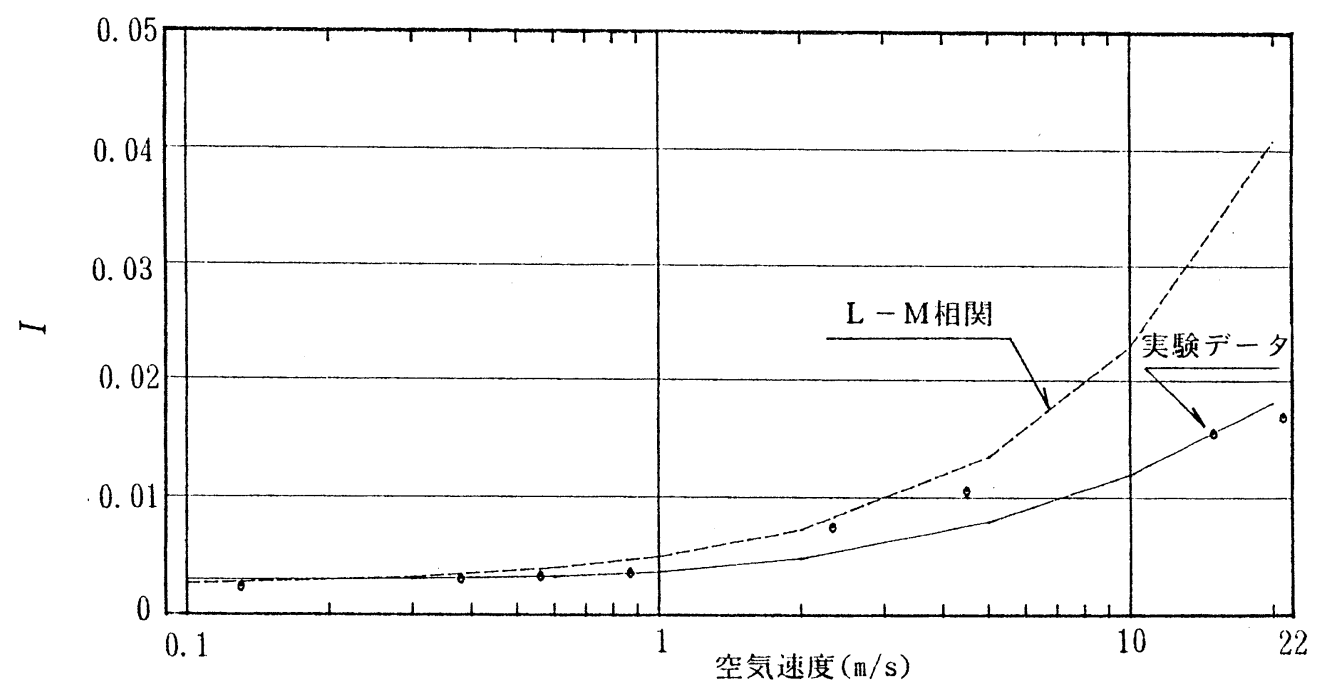

Fig. 21 圧損の比較（水速度 $V_{L}=1.0 \mathrm{~m} / \mathrm{s}$ ） 


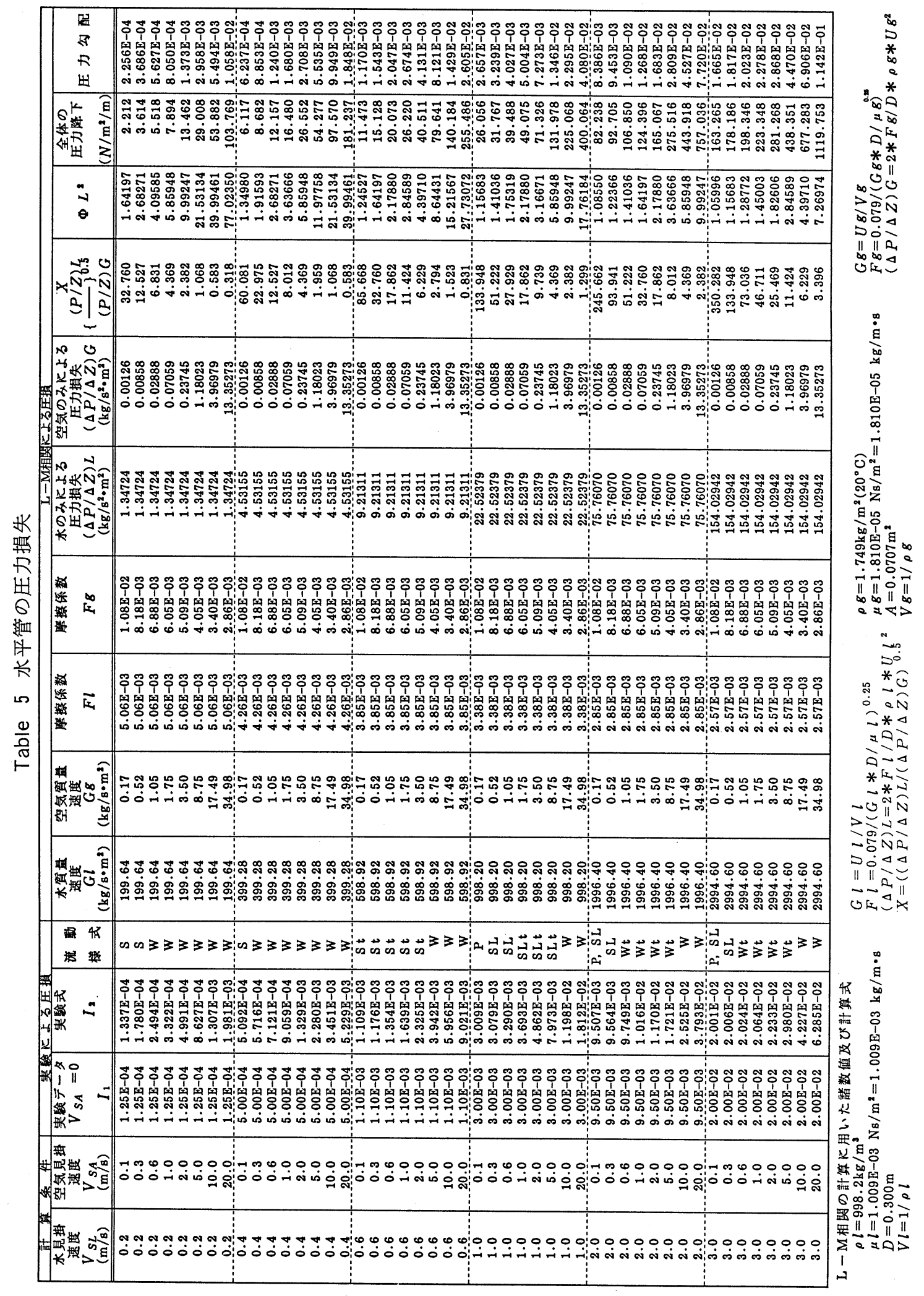


3.4.3 逆勾配の時の圧力損失

逆勾配時には、空気は逆勾配による浮力により速く流下する。同時に、その速度で水も押し 流す、いわゆるエアリフト効果があると考えられる。

一方、水は勾配から上流側に流れようといら力も働き、全体的な圧力差で下流に流下してい $<。$
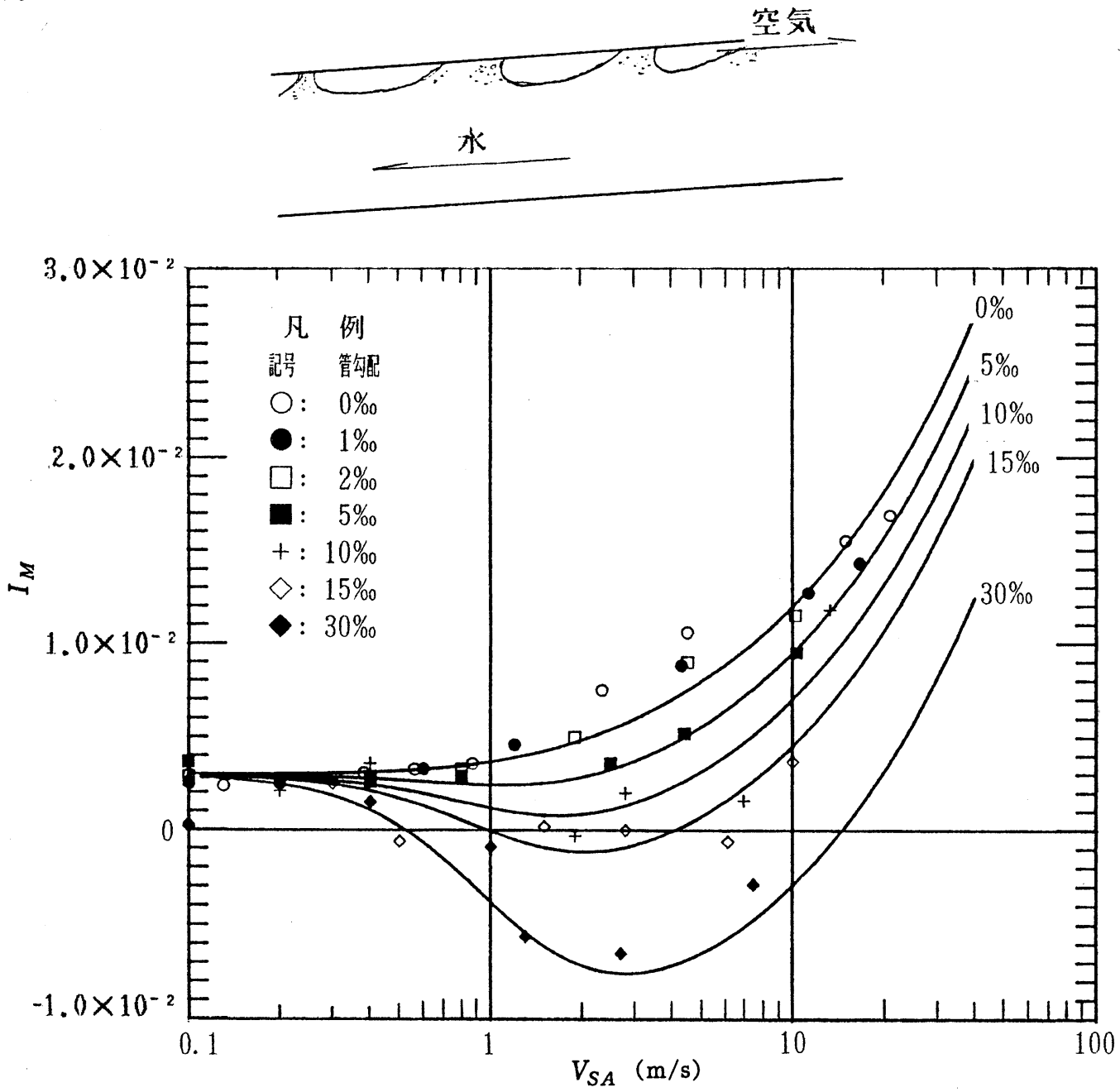

Fig. 22 逆勾配管における $V_{S A}$ と圧力損失 $I_{M}$

$$
\left(V_{S L}=1.0 \mathrm{~m} / \mathrm{s}\right)
$$

Fig. 22は、 $V_{S L}$ が $1 \mathrm{~m} / \mathrm{s}$ の時の $V_{S A}$ と圧力損失を逆勾配の程度により示したものである。

$V_{S L}$ が $0.3 \mathrm{~m} / \mathrm{s}$ よりさい時は、勾配に関わらず、ほぼ同じ圧力損失となっているが、 $V_{S A}$ の增加につれ、勾配の度合が大きいもの汪ど圧力損失が小さくなっている。特に、15\%、30\% では、マイナスの圧力損失となっている。

Fig. 23は、 $V_{S L}$ が $0.4 \mathrm{~m} / \mathrm{s}$ の時の $V_{S A}$ と圧力損失の関係を示している。逆勾配の大きいデー タがないため、傾向はつかみにくい。またFig.25,Fig.26,は、 $V_{S L}$ が $1.5 \mathrm{~m} / \mathrm{s}, 2 \mathrm{~m} / \mathrm{s}, 0.5 \mathrm{~m} / \mathrm{s}$, $0.7 \mathrm{~m} / \mathrm{s}$ 時のグラフである。 


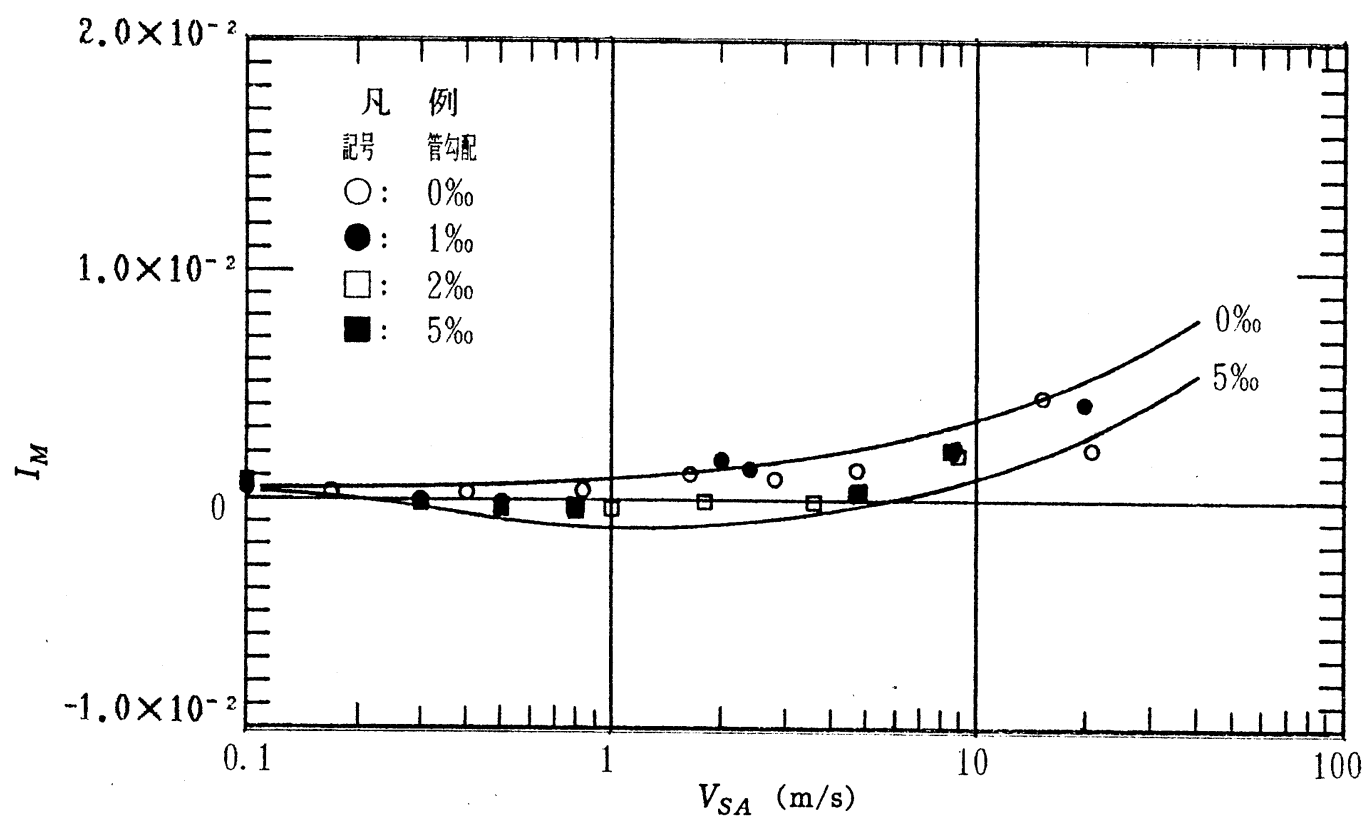

Fig. 23 逆勾配管における $V_{S A}$ と圧力損失 $I_{M}$

$$
\left(V_{S L}=0.4 \mathrm{~m} / \mathrm{s}\right)
$$

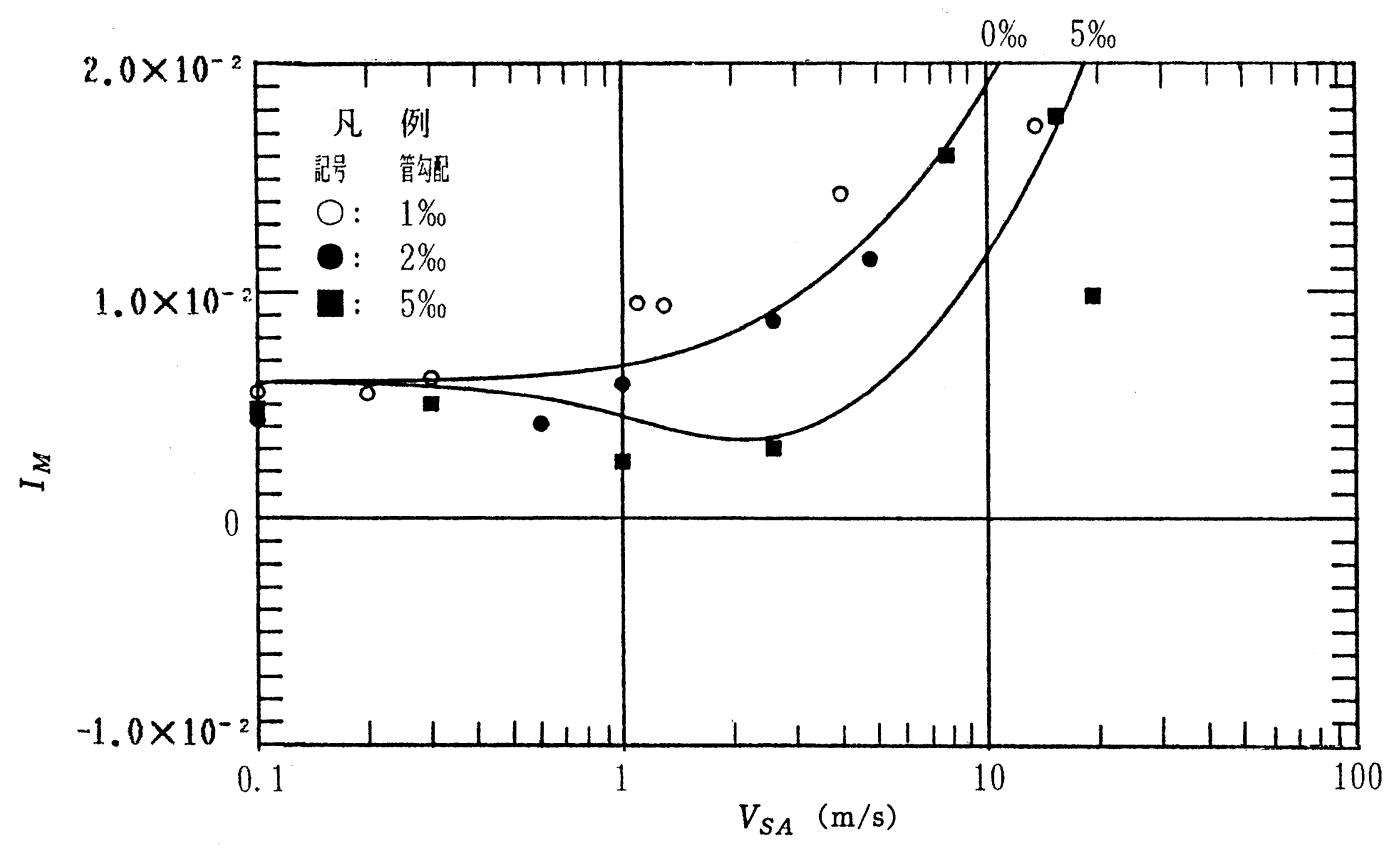

Fig. 24 逆勾配管における $V_{S A}$ と圧力損失 $I_{M}$

$$
\left(V_{S L}=1.5 \mathrm{~m} / \mathrm{s}\right)
$$




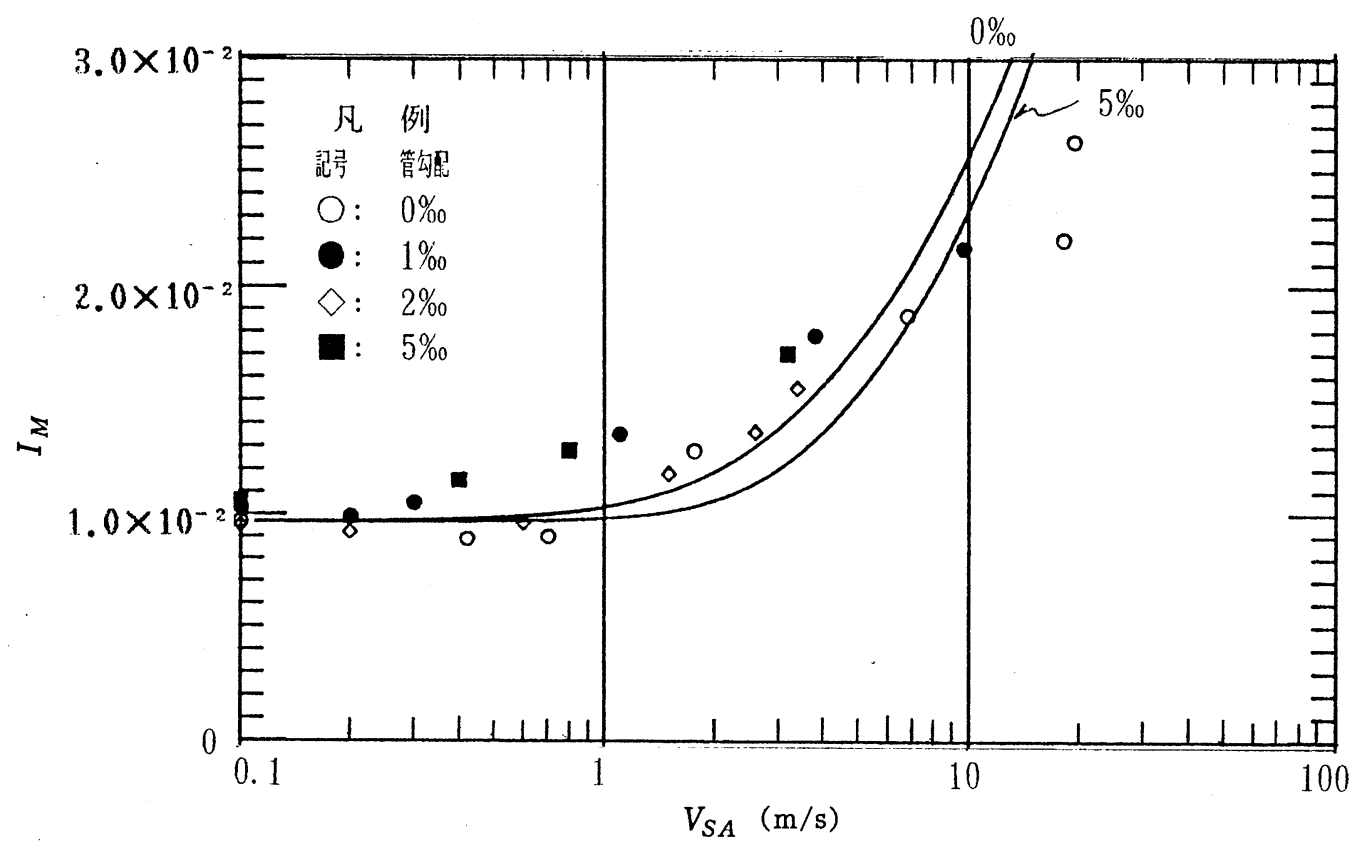

Fig. 25 逆勾配管における $V_{S A}$ と圧力損失 $I_{M}$

$$
\left(V_{S L}=2.0 \mathrm{~m} / \mathrm{s}\right)
$$

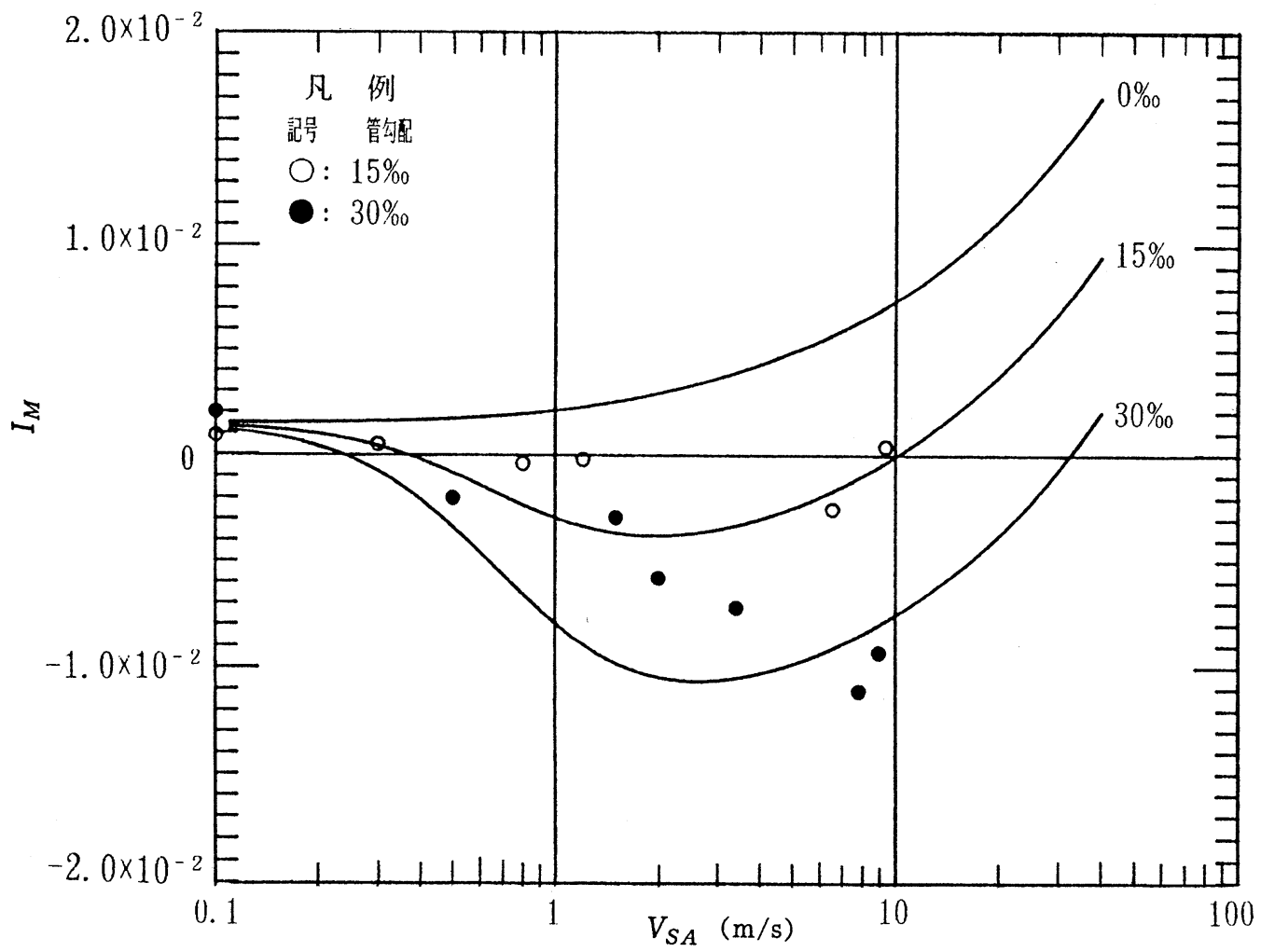

Fig. 26(1) 逆勾配管における $V_{S A}$ と圧力損失 $I_{M}$

$$
\left(V_{S L}=0.7 \mathrm{~m} / \mathrm{s}\right)
$$




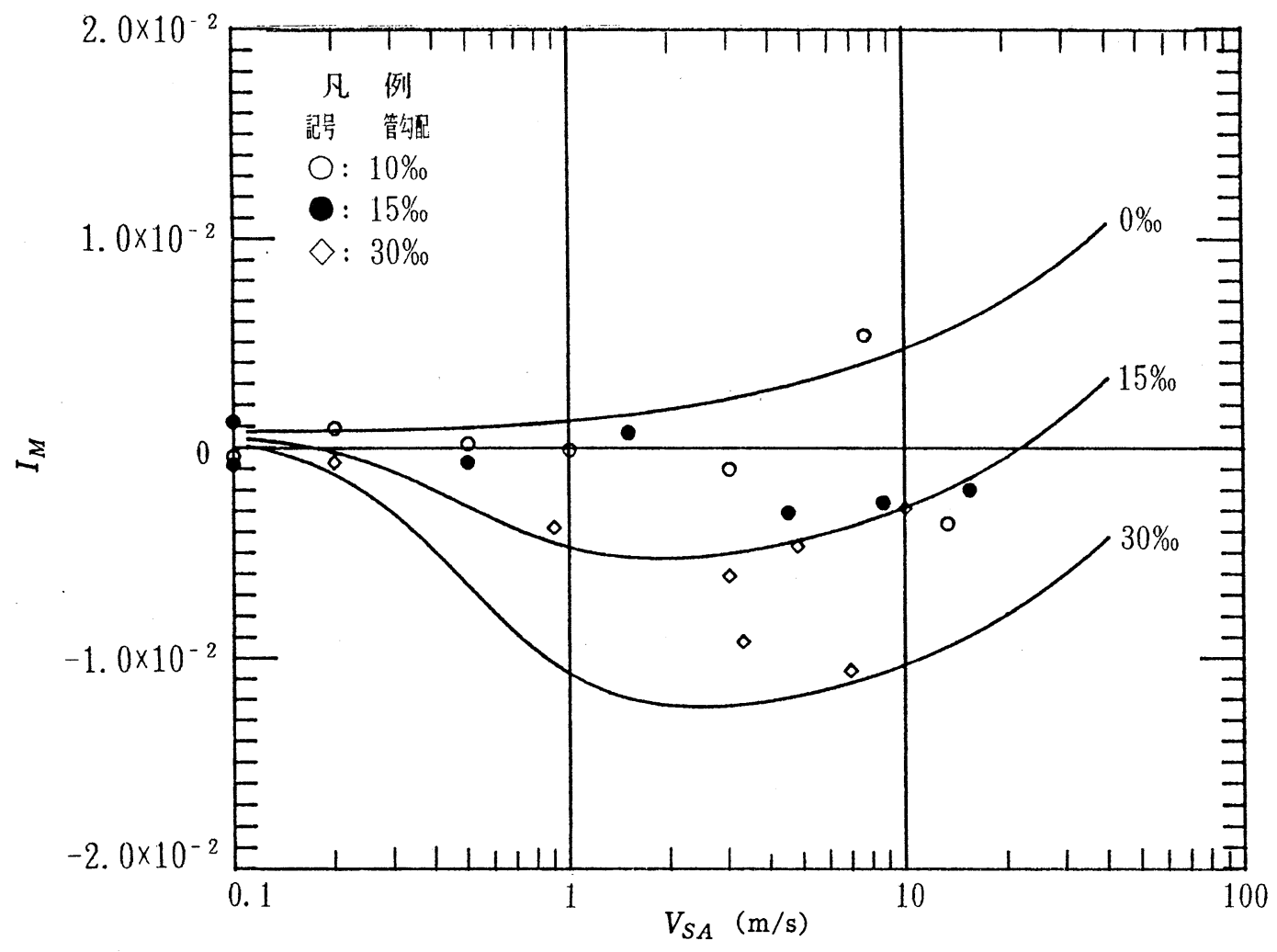

Fig. 26(2) 逆勾配管における $V_{S A}$ と圧力損失 $I_{M}$

$$
\left(V_{S L}=0.5 \mathrm{~m} / \mathrm{s}\right)
$$

以上のデータより次の実験式を求めた。

〈逆勾配による圧力損失の低下〉

$$
\begin{gathered}
I_{3}=I_{1} \times \frac{1}{2} \times \frac{V_{S A}{ }^{2}}{V_{S A}{ }^{2}+V_{S L}{ }^{2}} \\
\text { ここで、 } I_{1} \cdots \text { 逆勾配の勾配 } \\
V_{S A} \cdots 10 \mathrm{~m} / \mathrm{s} \text { 以下の状況 }
\end{gathered}
$$

式(10)において、 $V_{S A}$ が 0 に近い時は $I_{3}$ は 0 に近づき、 $V_{S A}$ が増大するに従って、 $I_{3}$ は逆 勾配の勾配の半分に近づく。

$$
I_{M}=I_{L O}\left\{\frac{\left(V_{S L}{ }^{2}+V_{S A}{ }^{2}\right)}{V^{2}}\right\}^{0.3}-\frac{1}{2} \times I_{1} \times \frac{V_{S A}{ }^{2}}{V_{S A}{ }^{2}+V_{S L}{ }^{2}}
$$

で表わされることとなる。

式(11)により、圧力損失を計算した線をFig. 22～Fig. 26に実線で示す。

3. 4 . 4 順勾配の時の圧力損失

水は順勾配管において管勾配により速く流下する。順勾配の管内に水を流した時は、一般に 自由水面を持つ開水路の状況となる。この洔、ボイド率は水流速によって主体的に定められる。 水流速と空気流速が大きくならないうちは、圧力損失は勾配によるものだけで一定である。 


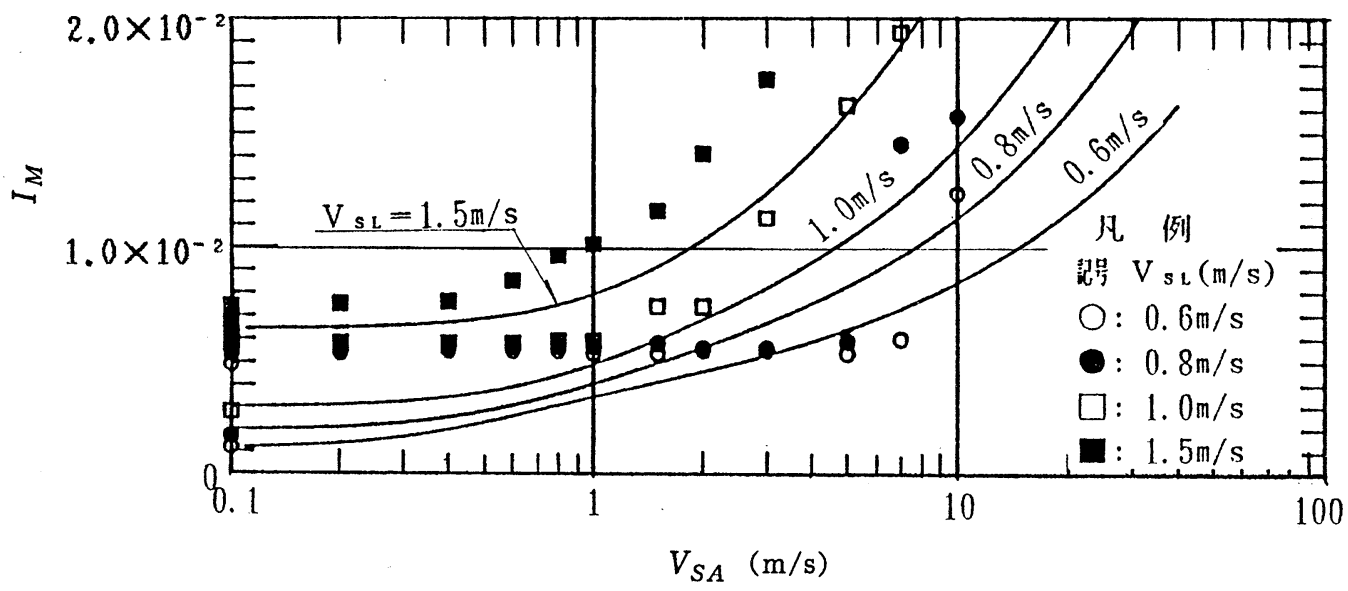

Fig. 27 順勾配管における $V_{S A}$ と圧力損失 $I_{M}$

Fig.27は、各 $V_{S L}$ の值の時の $V_{S A}$ と圧力勾配との関係を示したものである。

開水路の状態が成り立つ $V_{S L}=1 \mathrm{~m} / \mathrm{s}$ 以下の状況では、 $V_{S A}$ が小さいうちはおおむね $5 \%$ 示し、 $V_{S A}$ が大きくなるにつれ、ある点から $5 \%$ の勾配を超えたものとなっている。開水路の 状況では、 $V_{S L}$ は $1 \mathrm{~m} / \mathrm{s}$ が限度である。この値を超える $V_{S L}=1.5 \mathrm{~m} / \mathrm{s}$ は、 $V_{S A}$ が小さい状況 から圧力損失が $5 \%$ を超えて増加していく。逆勾配時の圧力損失の低下（エアリフト効果によ る）を示す。

式(10)を、順勾配にあてはめてみたのが、Fig.27の実線である。

$V_{S A}$ の増加時における $I_{3}$ の急激な増加とは少し離れているが、大まかな理解としては、式 (10)および式(11)で当面考えてみるものとする。

\section{4.まとめ}

大口径二相流の状況を把握するための実験を行った。

内径 $300 \mathrm{~m}$ 、直線延長 $100 \mathrm{~m}$ 及び $30 \mathrm{~m}$ の管を用い、水平及び順勾配、逆勾配の条件で流動様式、 ボイド率、圧力損失を調査した。各相の見かけ流速は、水 0 最大 $3.0 \mathrm{~m} / \mathrm{s}$ 、空気 0 最大 20 $\mathrm{m} / \mathrm{s}$ で実験した。その結果、データは相当のバラツキを示したが、

1. 分離流と間欠流の境界線については、水平管の場合、これまで発表されたものと打む ね同じ結果を示した。しかし、逆勾配の場合は1/1000くらいの低勾配でもほとんどすべて 間欠流を示した。また順勾配の場合、相当の範囲をで分離流を示した。

このように、大口径管の分離流と間欠流の境界は管勾配に大きく影響されることがわかっ た。

2、ボイド率も勾配によって大きな影響を受けることがわかった。

また、水平管及び逆勾配管において、空気見かけ速度 $V_{S A}$ と空気見かけ速度 $V_{S L}$ との 比が同じ場合、ボイド率はおおむね一定となる傾向が示された。

3 . 水平管の圧力損失勾配の実験式が求められた。

4. 逆勾配管および順勾配管の管勾配が圧力損失勾配に及ぼす影響について実験式が求めら れた。

ただ、実験装置の性格もあって、データは、相当のバラッキを示しており、今後同様の実験 が続けられる予定である。 


\section{参考文献}

1) Baker, O.: “Design of Pipe for Simultaneous Flow of Oil and Gas", Oil \& Gas J., 26 (July, 1954).

2) Baker, O.: "Simultaneous Flow of Oil and Gas", Oil \& Gas J., 53(1954).

3 ) Simpson H.C.:Rooney D.H. “Two-Phase Flow Studies in Large Diameter Horizontal Tubes”, NEL Report No. 677, National Engineering Laboratory, East Kilbride, Glasgow, (December, 1981).

4) Weisman J. : "Flow Pattern Identification in Co-Current Vapor-Liquid Flow", Proc. Japan-US Seminar on Two-Phase Flow Dynamics, Kobe(1979).

5) Taitel Y., Dukler A.E. : "A Model for Predicting Flow Regime Transition in Horizontal and Near Horizontal Gas-Liquid Flow”, AIChE J., 22-1,47(1976).

6) Lockhart R.W., Martinelli, R.C. : "Proposed Correlation of Data for Isothermal Two-Phase, Two-Component Flow in Pipes”, Chem.Eng. Progress, 45-1(1949).

7 ）赤川浩爾：気液二相流、コロナ社（1974）.

8 ）植田辰洋：気液二相流一流れと熱伝達一、養賢堂 (1981). 